2014 International Award Paper for Achievements in Bioorganometallic Chemistry

\title{
A Bioorganometallic Chemistry Perspective: Organometallic Chemistry at the Interface with Biology
}

\author{
Richard H. Fish* \\ Lawrence Berkeley National Laboratory, University of California, Berkeley, CA 94708, \\ USA
}

\begin{abstract}
A 41 year perspective on our bioorganometallic chemistry studies that included reactions of organotin compounds with cytochrome P450 enzymes, and their biomimics; identification of natural organoarsenic compounds in oil shale; reactions of an $\mathrm{Cp} * \mathrm{Rh}$ tris aqua complex with nucleobases; supramolecular $\mathrm{Cp} * \mathrm{Rh}-$ nucleobase complexes in host-guest chemistry; chemoselective reduction of $\mathrm{NAD}^{+}$biomimetic cofactors with an $\mathrm{Cp}$ * Rh-hydride to provide 1,4-NADH biomimics, in tandem with enzymatic catalysis for stereoselective reductions of achiral ketones to chiral alcohols, and including oxidation reactions with cytochrome P450 enzymes; synthesis and bioassays of organorhodium-hydroxytamoxifen breast cancer pharmaceuticals; and synthesis and bioactivity of Cp*Rh-G-Protein Coupled Receptor peptides, will be presented in this 2014 ISBOMC Award Paper.

\section{Introduction: Bioorganometallic Chemistry Projects at Lawrence Berkeley National Laboratory, University of California, Berkeley, and with other Collaborators from 1973-2014.}

For many years, I had been interested in adding a biological component to my organometallic chemistry research projects. After my $\mathrm{PhD}$ in organotin hydride reactions with allenes/dienes in 1965, I initially began my career in the chemical industry conducting studies on organoboron chemistry, 1965-1967, and then as a Postdoctoral/Lecturer in Chemistry at the University of California, Irvine in 1968-1969, conducting photochemical research. From 1970 to 1973, I took a position at a US Department of Agriculture Laboratory in Berkeley, CA, and was focused on environmental organometallic mercury chemistry, where $\mathrm{Hg}^{2+}$ was reacted with $\beta$ diketones to provide a new class of $\mathrm{C}$ - $\mathrm{Hg} \beta$-diketones complexes; at that time, $\mathrm{Hg}^{2+}$ and $\mathrm{CH}_{3} \mathrm{HgX}$ complexes were being found in seafood, and were also environmental toxins in water. It is important to remember that methyl-B12 biomethylates many toxic metal; for example, $\mathrm{Hg}$, $\mathrm{Sn}$, As, Se, etc., and the $\mathrm{CH}_{3}-\mathrm{M}$ analogues of these inorganic metals were found to be extremely more toxic than their inorganic metal counterparts, to humans.

In 1973, I was invited to collaborate on a NIEHS grant on the UC Berkeley campus, with a focus on the metabolism of tributyltin derivatives with cytochrome P450 enzymes, since these organotin compounds were being sprayed on food products for pest control. This latter project provided me with a new direction, Bioorganometallic Chemistry, and at the interface with Biology. In this ISBOMC'14 award paper, I will start from 1973, and peruse the Bioorganometallic Chemistry projects we have conducted up to the present at LBNL/UC Berkeley, and with colleagues around the globe. 
Therefore, this award paper will focus on our Bioorganometallic Chemistry programs from 1973-2014. Thus, the following 41 year overview of structures, that are shown below (counterclockwise from left), represent all the important findings of our studies: Cyclohexyltriphenyltin metabolism studies with Cytochrome P450 enzymes to provide the trans-4-hydroxycyclohexyltriphenyltin metabolite as the major compound; $\left[\mathrm{Cp} * \mathrm{Rh}\left(\mathrm{H}_{2} \mathrm{O}\right)_{3}\right](\mathrm{OTf})_{2}$ reactions with nucleobases; for example, 1-methylthymine (1-MT), providing, at $\mathrm{pH} 10$, a unique complex of anion and cation components, and further stabilized by $\pi-\pi$ interactions of the $\mathrm{Cp} * \mathrm{Rh}$ moiety of $[(\mathrm{Cp} * \mathrm{Rh}) 2(\mu-\mathrm{OH}) 3]^{+}$with the 1-MT linear complex, $\left[\operatorname{Rh}\left(\eta^{1}\left(\mathrm{~N}^{3}\right)-1-\mathrm{MT}\right)_{2}\right]^{-}$; [cis-Cp*Rh-hydroxytamoxifen $](\mathrm{OTf})_{2}$ as a breast cancer antagonist drug formed in a novel $\mathrm{N}-\pi$ rearrangement; $2 \mathrm{D}$ NMR structure of $\left[\left(\eta 6-\mathrm{Cp} * \mathrm{Rh}^{-} \mathrm{Tyr}^{3}\right) \text {-octreotide }\right]^{2+}$ formed in the reaction of the G-proteincoupled receptor peptide, $\left[\mathrm{Tyr}^{3}\right]$-octreotide, with $\left[\mathrm{Cp} * \mathrm{Rh}\left(\mathrm{H}_{2} \mathrm{O}\right)_{3}\right](\mathrm{OTf})_{2}$, at $\mathrm{pH} 5.5$; The synthon for many of our aqueous reactions, $\left[\mathrm{Cp} * \mathrm{Rh}\left(\mathrm{H}_{2} \mathrm{O}\right)_{3}\right](\mathrm{OTf})_{2}$; Biomimetic cofactor, with a Cytochrome P450 BM3 Double Mutant enzyme, for biological oxidation reactions; Host, cyclic trimer, $\left[\mathrm{Cp}^{*} \mathrm{Rh}\left(2^{\prime} \text {-deoxyadenosine }\right]_{3}(\mathrm{OTf})_{3}\right.$, docking with Guest, L-Tryptophan; and identification of Phenylarsonic acid, as a natural product in Kerogen, the biogeochemical fossil product, emanating largely from lipid fractions of ancient algae. Finally, the burgeoning Bioorganometallic Chemistry discipline represents exciting new vistas at the interface with biology.

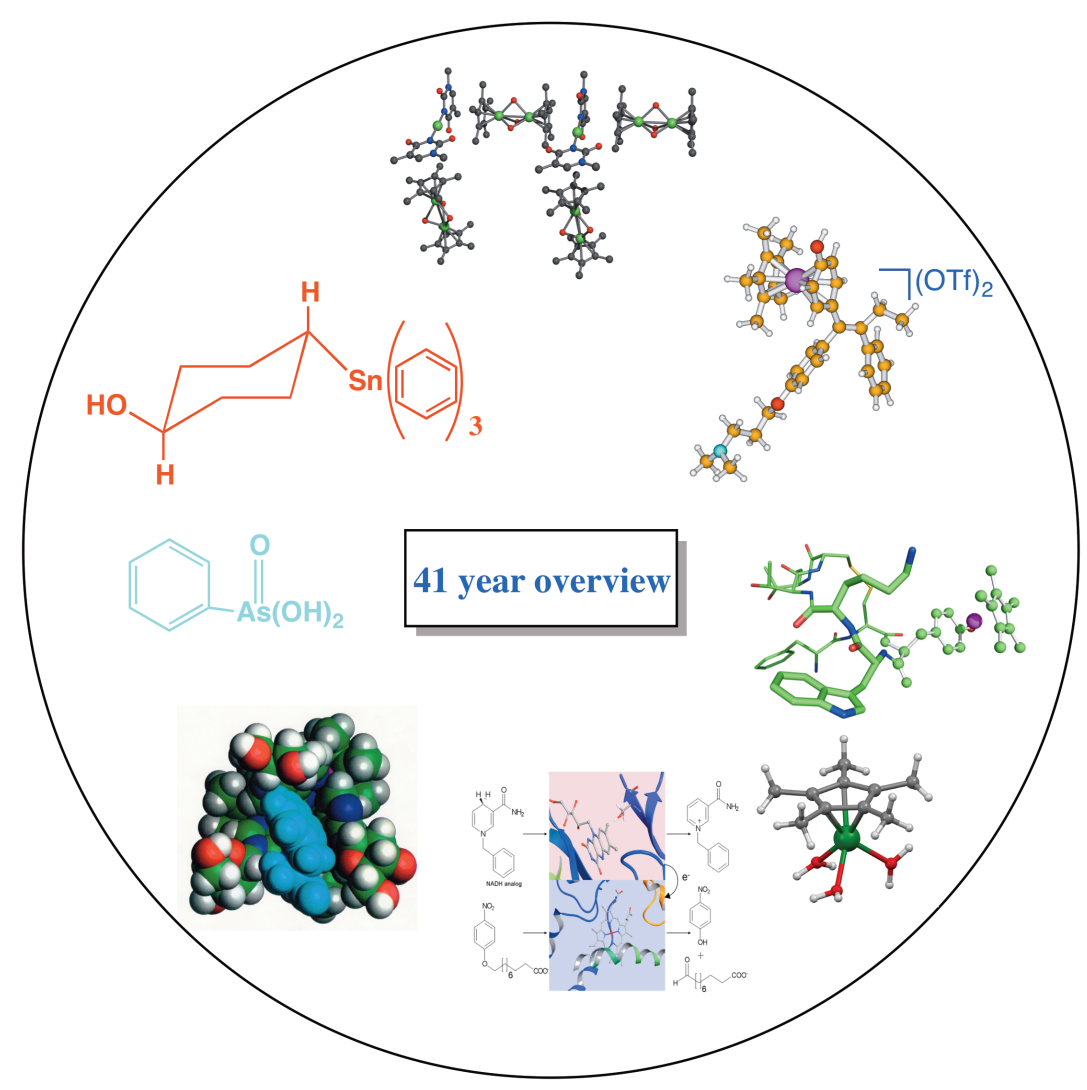




\section{Bioorganotin Metabolism Chemistry with Tributyltin Acetate, and a Cyclohexyltriphenytin Compound for Chemo and Stereoselectivity, and the Implications of a Free Radical Mechanism.}

As stated, our studies in the field of bioorganometallic chemistry began in 1973. We were interested in the metabolism of organotin compounds, which were being utilized as pesticides in agricultural applications. The focus was on the metabolism of tributyltin compounds in reactions with rat liver microsomes, P450 enzymes for biological oxidation studies, for obvious environmental and health reasons. Thus, we discovered the first metabolites of tributyltin acetate with P450 enzymes, and also studied their toxicology. Therefore, a new area of organometallic chemistry research, which we coined at the time, Bioorganotin Chemistry, was initiated (Eq. 1). ${ }^{\text {1a-c }}$
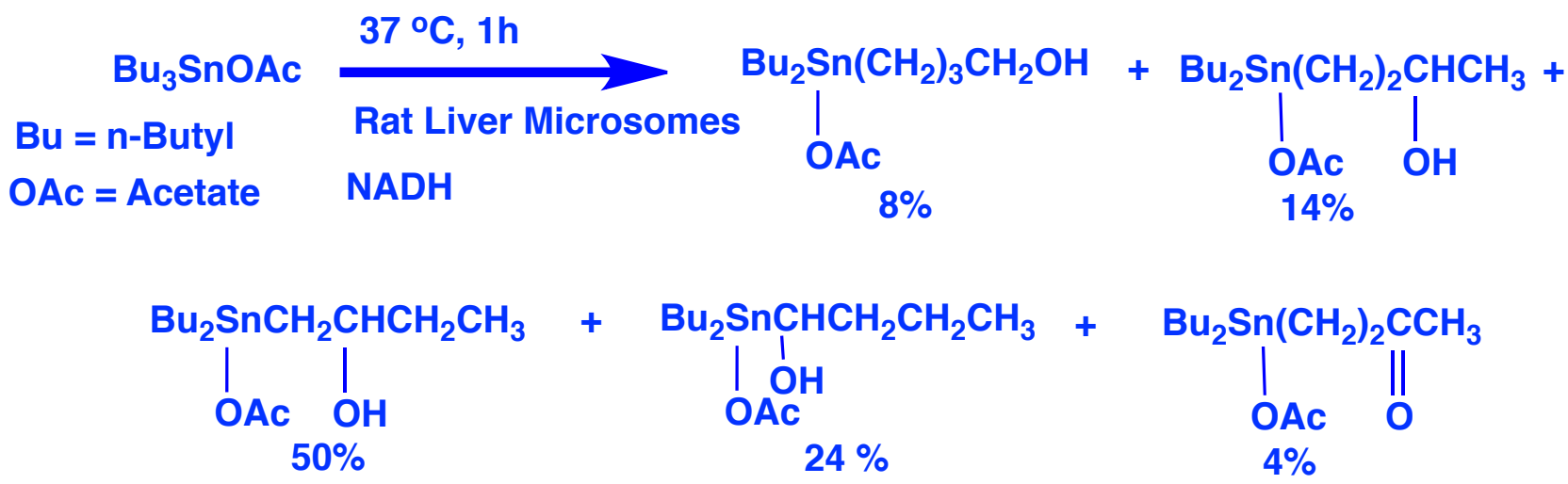

It was also important to study the chemo and stereoselectivity of these biological P450 enzyme reactions, and to understand more about a possible free radical mechanism; therefore, we studied cyclohexyltriphenyltin, and were able to define both aspects, with P450 rat liver microsomes, ${ }^{2}$ and their biomimetic models, Mn and Fe porphyrin derivatives (Figure 1). ${ }^{3}$ 


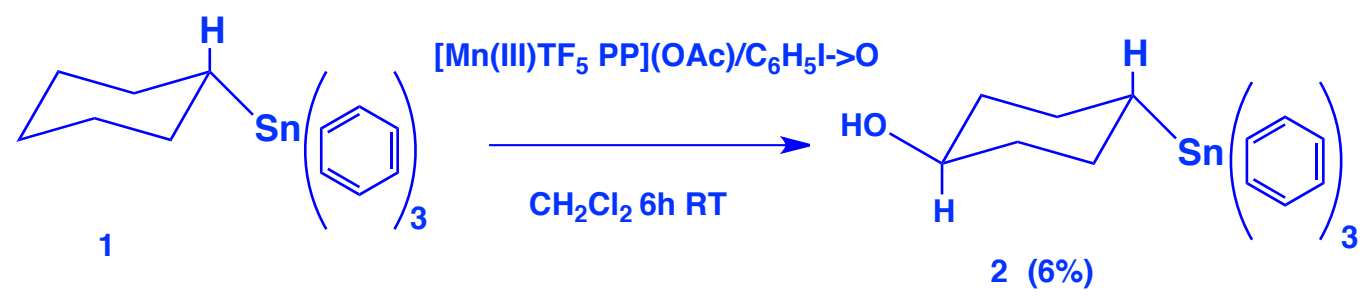

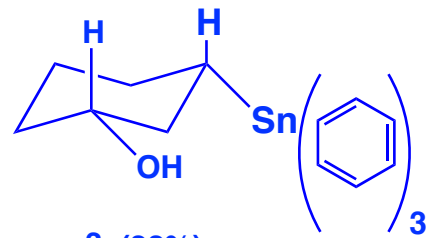

$3(22 \%)$

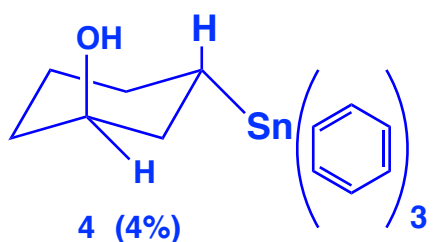

$4(4 \%)$

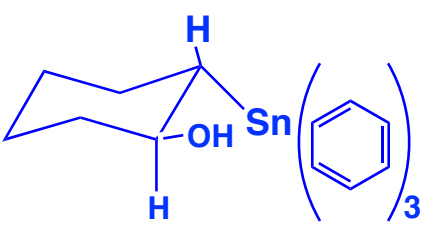

$5(69 \%)$

Figure 1: Biomimetic Oxidation of Cyclohexyltriphenyltin, 1, with $\left[\mathrm{Mn}(\mathrm{III}) \mathrm{TF}_{5} \mathrm{PP}\right](\mathrm{OAc}) /$ Iodosobenzene as Precatalyst/Oxygen Transfer Agent

The chemo and stereoselectivity in the hydroxylation reaction of cyclohexyltriphenyltin, $\mathbf{1}$, with biomimetic precatalysts that mimic the active site of the cytochrome P-450 monooxygenase enzyme, iron(III) and manganese(III) tetrakis(pentafluorophenyl)porphyrin derivatives, $\left[\mathrm{Fe}(\mathrm{III})\right.$ or $\left[\mathrm{Mn}(\mathrm{III}) \mathrm{TF}_{5} \mathrm{PP}\right](\mathrm{Br}, \mathrm{OAc})$, was studied utilizing the oxygen transfer agent, iodosylbenzene, and these results were compared to those obtained with the P-450 enzyme from rat liver microsomes (Table 1). ${ }^{3}$ The $\left[\mathrm{Mn}(\mathrm{III}) \mathrm{TF}_{5} \mathrm{PP}\right](\mathrm{OAc})$ biomimetic catalyst provided a $22 \%$ conversion of 1 to a mixture of cis- and trans-hydroxycyclohexyltriphenyltin compounds that included the trans-4 (5.9\%), 2; cis-3 (22\%), 3; trans-3 (3.3\%), 4; and trans-2 (68.8\%), 5, isomers. The chemoselectivity on a per hydrogen basis showed a $\mathrm{C} 4: \mathrm{C} 3: \mathrm{C} 2: \mathrm{C} 1$ ratio of 1:2:6:0 and a high stereoselectivity for equatorial over axial hydroxyl products with a EQ/AX ratio of 29 . The corresponding $\mathrm{Fe}(\mathrm{III}) \mathrm{TF}_{5} \mathrm{PP}(\mathrm{Br})$ catalyst gave the same pattern of hydroxylation as with the above-mentioned Mn catalyst. In comparison to the P-450 enzyme, which had a different chemoselectivity ratio on a per hydrogen basis for C4:C3:C2:C1 of 109:7:1:0, the biomimics appear to have less steric requirements at the putative reactive site, $\mathrm{Mn}=\mathrm{O}$, and was not encumbered by an enzyme pocket, which was limited both by size and steric consequences. 
Table I. Comparison of the Chemoselectivity in the Hydroxylation of Compound 1 with Biomimic, [Mn(III)TF 5 PP] $(\mathrm{OAc})$, and a P-450 Enzyme from Rat Liver Microsomes

\begin{tabular}{ccc}
\hline Compounds $^{\mathrm{a}}$ & {$\left[\mathrm{Mn}(\mathrm{III}) \mathrm{TF}_{5} \mathrm{PP}\right](\mathrm{OAc}), \%$} & P-450 enzyme $^{\mathrm{b}}, \%$ \\
\hline $2^{\mathrm{c}}$ & 6 & 86 \\
$3^{\mathrm{d}}$ & 22 & 7 \\
$4^{\mathrm{d}}$ & 4 & 3 \\
$5^{2}$ & 69 & 2
\end{tabular}

${ }^{a}$ See Figure 1 for structures 2-5. ${ }^{b} \mathrm{P}-450$ enzyme from rat liver microsomes (see ref 4). ${ }^{\mathrm{c}}$ The ketone of $\mathbf{2}$ was present in $1.9 \%$. ${ }^{\mathrm{d}}$ The ketone from $\mathbf{3}$ and $\mathbf{4}$ was present in $1.4 \%$.

Mechanistically the tin atom also appeared to control the chemoselectivity of the hydroxylation reaction as shown in Scheme 1, by the fact that $\mathbf{3}$ and $\mathbf{5}$ were the major hydroxylation products, due to a stabilization of radical intermediates on carbons 2 and 3 by the carbon-tin $\sigma^{-}$-bond. Moreover, the hydroxyl rebound reaction to give products $\mathbf{2 - 5}$ also appeared to be stereoselective for the sterically more favorable equatorial product.

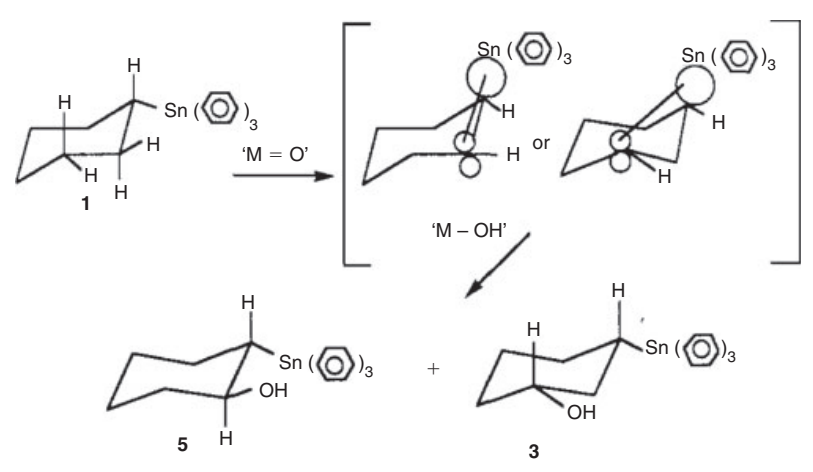

Scheme 1: Carbon-Tin $\sigma^{-}$-bond stabilization of the developing carbon $2 p$ orbital free radical during the oxidation reaction.

What the preceding experiments have clearly shown was that in the hydrophobic pocket of cytochrome $\mathrm{P} 450$, the cyclohexyl group must be orientated with the axial carbon-hydrogen on $\mathrm{C} 4$, being closer to the porphyrin $\mathrm{Fe}=\mathrm{O}$ site of oxygen insertion, ${ }^{3}$ while the solution results do not have those restrictions, and thus, the chemoselectivity was opposite to the enzyme results; i.e., the $\mathrm{C}$-Sn $\sigma^{-}$-bond overlaped with the $\mathrm{C}$ radical on $\mathrm{C} 2$ and $\mathrm{C} 3$ dictates chemoselectivity (Scheme 1). ${ }^{3}$ The metabolism studies of the abovementioned organotin compounds were a prelude to the future use of these types of compounds as anti-cancer drugs, since this aspect would be an important component of any new organotin drug brought to clinical trials. A comprehensive review of the organotin anti-cancer drug discipline provided an overview of their veracity as new metal-based drugs. ${ }^{4}$ 


\section{Organometallic Geochemistry: Isolation and Identification of Natural Organoarsenic Compounds from Green River Formation Oil Shale, an Ancient Biogeochemical Material}

The molecular characterization of organometallic compounds, which occur as natural products in fossil biogeochemical material, has recently become a significant area of research, because of the importance of these compounds in emerging synthetic fuel processes, as well as their impact on the environment. ${ }^{5 a-c}$ By using a high performance liquid chromatograph coupled to a graphite furnace atomic absorption spectrometer (HPLC-GFAA) as an element-selective detector, we had identified methyl- and phenylarsonic acids, as well as the inorganic ion, arsenate, in oil shale retort waters and the corresponding shale oils produced by pyrolysis of oil shale, and found that the organoarsonic acids mentioned above also occur, but in association with iron-containing macromolecules with molecular weights in the range of $2000-4000$ Daltons. ${ }^{5 a, b, 6}$

In order to discern whether these compounds were natural products in the precursor of the shale oil and the retort waters, or were formed during pyrolysis, we had examined a Green River Formation oil shale, which is a fine-grained sedimentary rock containing appreciable quantities of organic material. It consisted of three fractions: kerogen, bitumen, and an inert substance. Kerogen and bitumen, which constitute the organic material, are generally regarded as biogeochemical fossil products, emanating largely from lipid fractions of ancient algae, and forming the ubiquitous oil source matrix in shales. The Green River Formation oil shale sample was crushed and Soxhlet extracted with methanol. This effectively removed about $20 \%$ of the total arsenic contained in this oil shale sample. Following evaporation and filtration, we analysed the extract by the coupled HPLC-GFAA arsenic-specific technique, using a Dionex anion exchange column to show methyl- and phenylarsonic acids, and the arsenate ion (Figure 2). ${ }^{6}$

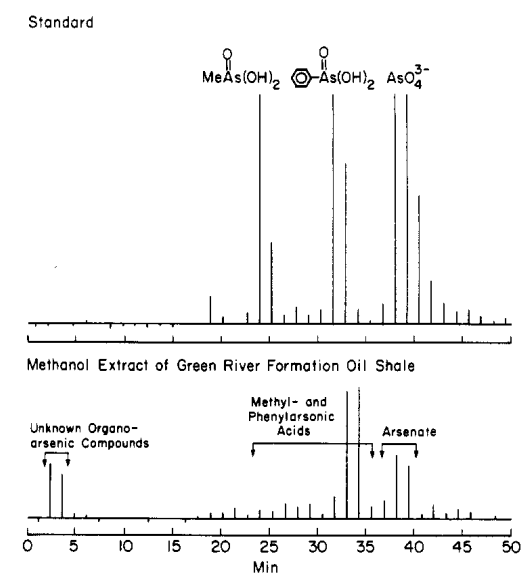

Figure 2: HPLC-GFAA Chromatograph of the arsenic-specific analysis of the methanol extract of Green River Oil Shale 
In order further verify the preceding results with the HPLC-GFFA arsenic-specific analysis shown in Figure 2, we used derivatization methods, followed by GC-EIMS analysis, to further identify these natural organoarsenic and inorganic arsenic compounds found in Green River Oil Shale. ${ }^{7}$ We had studied the reactions of organoarsenic compounds, methyl- and phenylarsonic acids, with 3-methylcatechol (eq 2) in order to synthesize derivatives that could be volatile enough for GC-EIMS analysis. ${ }^{8}$

Figure 3 shows the GC-EIMS results with the authentic bis(catacholates) of methyl- and phenylarsonic acids (left), and the HPLC purified methanol extract of the Green River oil shale sample (right) to show that indeed both methyl- and phenylarsonic acids were present in the oil shale. The identification of these natural organoarsenic and inorganic arsenic compounds were the first ever identified in ancient biogeochemical material of the oil shale fossilization process from algae, that eventually formed the ubiquitous distribution of kerogen in oil shale. ${ }^{6,7}$
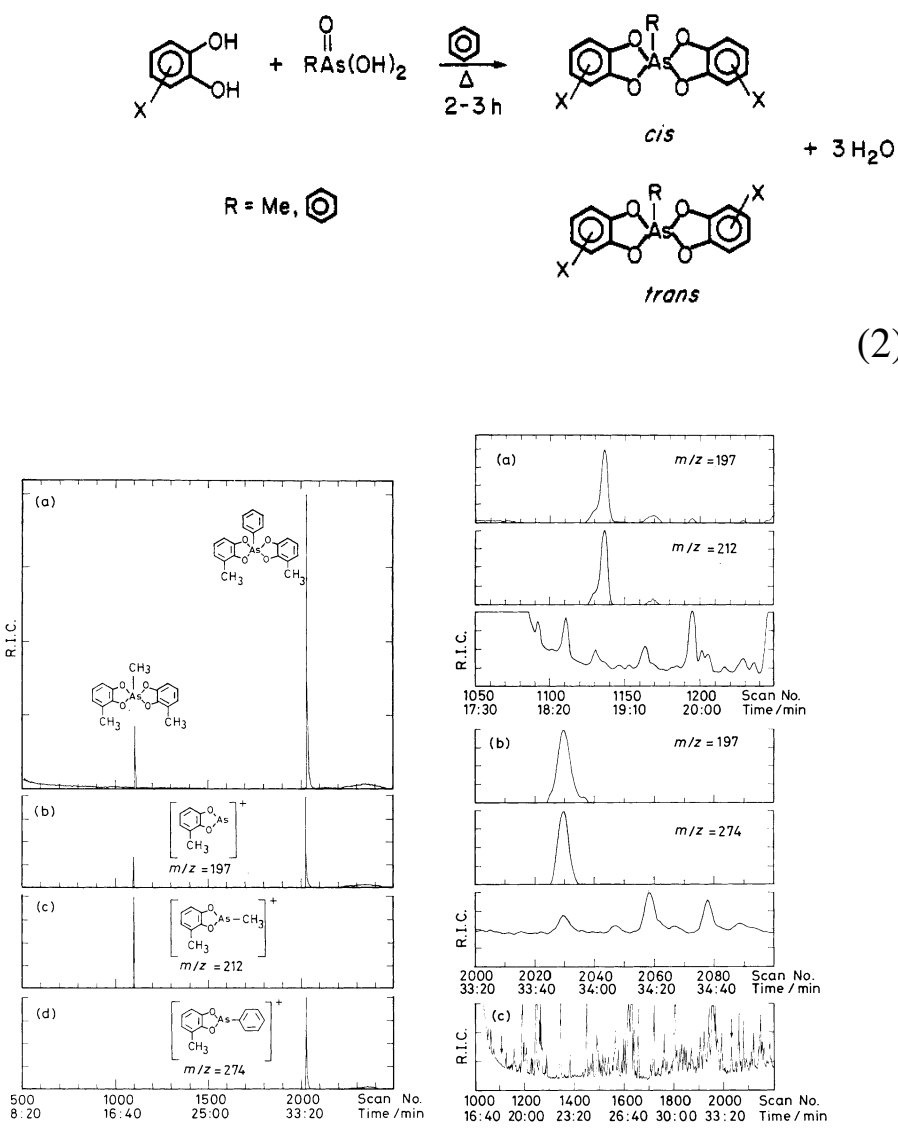

Figure 3. Left (a) GC-EIMS analysis of authentic bis(3-methylcatecholates) of methyland phenylarsonic acids with reconstructed ion chromatogram; (b) selected ion chromatograms with the $m / z, 197$ ion; (c) the $m / z 212$ ion for the bis(catecholate) of methylarsonic acid; (d) the $\mathrm{m} / \mathrm{z} 274$ ion for the bis(catecholate) of phenylarsonic acid. Right (a) GC-EIMS of the 3-methylcatecholate derivatized Green River Shale Oil extract (HPLC purified); (a) Selected ions for the bis(catecholate) of methylarsonic acid; (b) Selected ions for bis(catecholate ) of phenylarsonic acid; (c) Extract GC-EIMS profile. 


\section{Bioorganometallic Chemistry of $\left[\mathrm{Cp}^{*} \mathrm{Rh}\left(\mathrm{H}_{2} \mathrm{O}\right)_{3}\right](\mathrm{OTf})_{2}$ with Nucleobases: X-Ray Structures}

In the early 1990s, NIH was initiating a program to map and sequence the human genome, and we were interested in how the $\mathrm{Cp} * \mathrm{Rh}-\mathrm{N}$-heterocycle chemistry we had pursued during the $80 \mathrm{~s}$ and $90 \mathrm{~s}$ could be utilized for this purpose. Moreover, we thought it imperative to conduct this new Bioorganometallic Chemistry research in water to make it more relevant to the biological systems. The focus of our collaborators was to design a method to anchor large DNA molecules to the gold electrode array on the stage of an epifluorescence microscope for mapping and sequencing $\lambda$ DNA, as a DNA model 50,000 base pair oligonucleotide. We were able to utilize $\left[\mathrm{Cp}^{*} \mathrm{Rh}\left(\mathrm{H}_{2} \mathrm{O}\right)_{3}\right](\mathrm{OTf})_{2}$ and a synthesized 20 mer, consisting of a 10 mer of adenosine bases, and a 10 mer with the complementary sequence of the end $\lambda$ DNA bases, for these purposes. However, even though this approach was successful in binding $\lambda$ DNA to the gold electrode array, we did not know how the $\left[\mathrm{Cp}^{*} \mathrm{Rh}\left(\mathrm{H}_{2} \mathrm{O}\right)_{3}\right](\mathrm{OTf})_{2}$ was binding to the 20 mer.

Therefore, we embarked on a project to study the reactions of $\left[\mathrm{Cp} * \mathrm{Rh}\left(\mathrm{H}_{2} \mathrm{O}\right)_{3}\right](\mathrm{OTf})_{2}$ with individual nucleobases, in water, and as a function of $\mathrm{pH}$. At that time, the 1990s, relatively little was know about the $\mathrm{pH}$ dependent nature of the reactions of organometallic aqua complexes with DNA bases. We found that the $\mathrm{pH}$ dictated the structure of the $\mathrm{Cp} * \mathrm{Rh}-\mathrm{DNA}$ base complex. For example, the reaction of 9-methyladenine (9-MA) with $\left[\mathrm{Cp} * \mathrm{Rh}\left(\mathrm{H}_{2} \mathrm{O}\right)_{3}\right](\mathrm{OTf})_{2}$ provided a cyclic trimer at $\mathrm{pH} 6.8$ (pD 7.2) (Figure 4), whose structure, complex 6, at that time, was unprecedented for an organometallic-DNA base complex. ${ }^{9}$

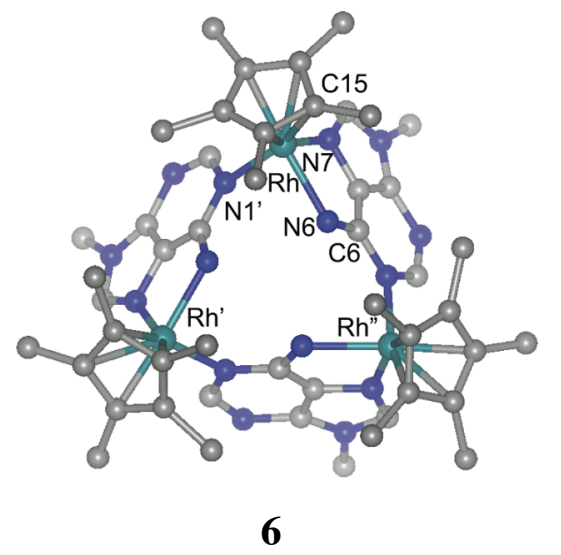

Figure 4: X-Ray Structure of trication, $\left[\mathrm{Cp} * \mathrm{Rh}\left(\mu-\eta^{1}(\mathrm{~N} 1): \eta^{2}(\mathrm{~N} 6, \mathrm{~N} 7)-9-\mathrm{MA}\right]_{3}(\mathrm{OTf})_{3}\right.$ (triflate anions not shown for simplicity), 6.

This was the paradigm for all the other $\mathrm{Cp} * \mathrm{Rh}-\mathrm{DNA}$ base structures we solved by single crystal $\mathrm{X}$-ray analysis, with $\mathrm{pH}$ dictating the structure of the complexes that formed. This was also illustrated with 9-methyl/ethylhypoxanthine (9-MH/9-EH) in Figure 5, where a different structure, based on the pKa of the hypoxanthine ligand, was obtained, complexes 7, 8, and 9. 

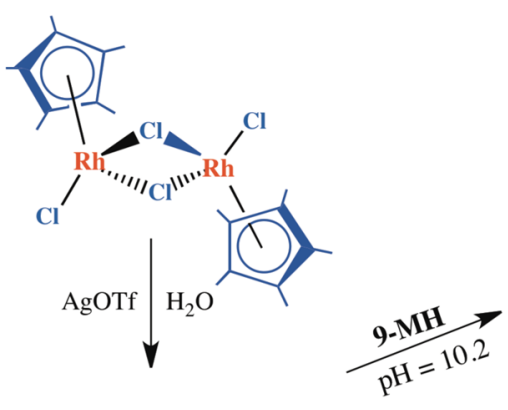

$\left[\mathrm{Cp} * \mathrm{Rh}\left(\mathrm{H}_{2} \mathrm{O}\right)_{3}\right](\mathrm{OTf})_{2}$

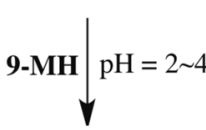
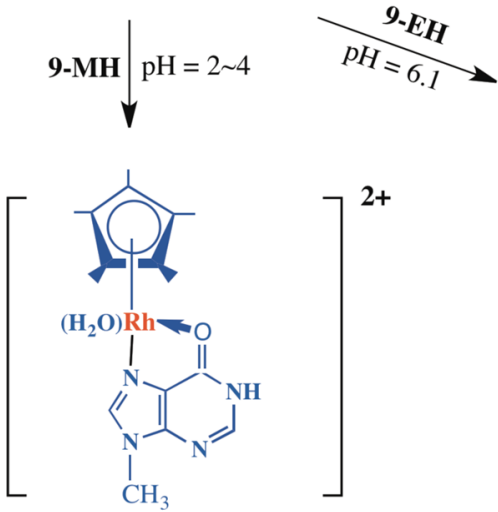

7
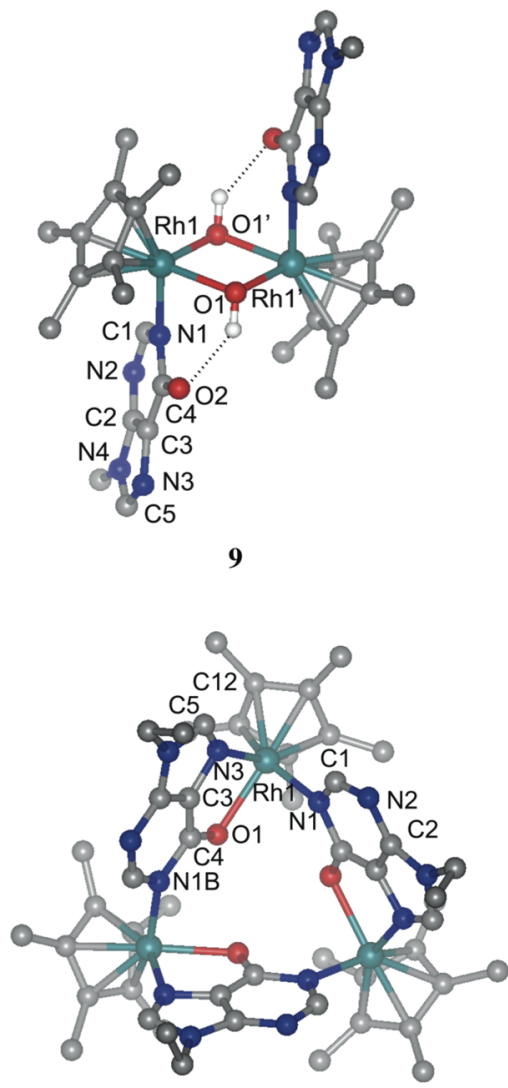

8

Figure 5: $\mathrm{Cp} * \mathrm{Rh}-h y p o x a n t h i n e ~ s t r u c t u r e s, ~ 7,8$, and 9, dictated by $\mathrm{pH}$.

The X-ray structures of two other $\mathrm{Cp} * \mathrm{Rh}$-nucleobase complexes, 1-methyl cytosine and 1-methylthymine, as a function of $\mathrm{pH}, 5.4$ and 10, respectively, were also elucidated by X-ray analysis, complexes $\mathbf{1 0}$ and $\mathbf{1 1}$ are shown in Figure 6.9

Since DNA may possibly be implicated as a site for metal-based drug's mode of action, our studies on individual DNA bases, nucleotides, and nucleosides, in water, were important for structure-activity relationships, and the effect of $\mathrm{pH}$ on reactivity. 


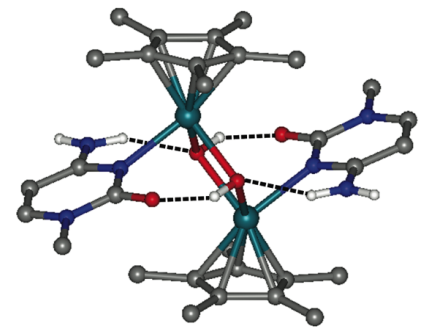

10

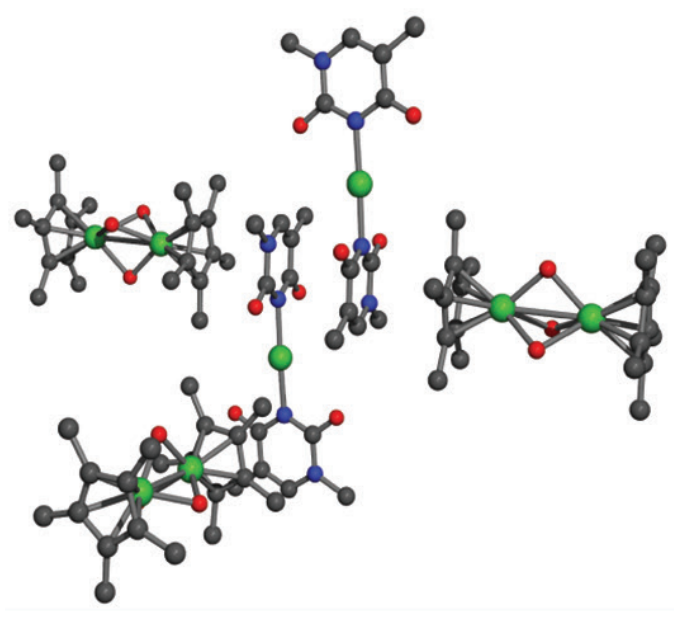

11

Figure 6. X-ray structures of trans- $\left[\mathrm{Cp} * \mathrm{Rh}\left(\eta^{1}(\mathrm{~N} 3)-1 \text {-methylcytosine }\right)(\mu-\mathrm{OH})\right]_{2}(\mathrm{OTf}) 2$, 10; $2\left[\mathrm{Rh}\left(\eta^{1}\left(\mathrm{~N}^{3}\right)-1-\mathrm{MT}\right) 2\right]^{-} \cdot 3\left[\left(\mathrm{Cp}^{*} \mathrm{Rh}\right) 2(\mu-\mathrm{OH}) 3\right]^{+}, \mathbf{1 1}$

\section{The Reaction of $\left[\mathrm{Cp} * \mathrm{Rh}\left(\mathrm{H}_{2} \mathrm{O}\right)_{3}\right](\mathrm{OTf})_{2}$ with Co-factor, Nicotinamide Adenine Dinucliotide (NAD ${ }^{+}$)}

We were also particularly intrigued by the common cyclic trimer structure that occurs with all 9-substituted adenine derivatives we have perused. This cyclic trimer, trication structure, $\left[\mathrm{Cp}^{*} \mathrm{Rh}\left(\mu-\eta^{1}(\mathrm{~N} 1): \eta^{2}(\mathrm{~N} 6, \mathrm{~N} 7)-9 \text {-substituted adenine }\right]_{3}{ }^{3+}\right.$, with complex 6 as an example, forms via a self-assembly mechanism and provides this thermodynamically favored product, where the N-9-adenine substituent was alkyl, ribose, or a ribose phosphate ester. Thus, an adenine derivative that sparked our interest was nicotinamide adenine dinucleotide $\left(\mathrm{NAD}^{+}\right)$, an important co-factor in enzymatic reactions that utilizes its reduced form, 1,4-NADH, as a hydride source in chiral reduction reactions. ${ }^{10}$

The ${ }^{1} \mathrm{H}$ NMR spectroscopy of $\mathrm{NAD}^{+}$and $\left[\mathrm{Cp}^{*} \mathrm{Rh}\left(\mathrm{H}_{2} \mathrm{O}\right)_{3}\right](\mathrm{OTf})_{2}$ showed very unambiguously that as you increase the $\mathrm{pH}$ from 3.0 to 6.0 , two diastereomeric compounds are evident ( $\mathrm{Cp}^{*}$ signals at $1.670 ; 1.673 \mathrm{ppm}, \mathrm{pH} 6.0$ ), and that these diastereomers have a very narrow stability range; i. e., at $\mathrm{pH}$ values less than 6.0 , there is a presumed mixture of [Cp*Rh(NAD)] and $\mathrm{Cp}^{*} \mathrm{Rh}$ aqua intermediates (at least $8 \mathrm{Cp} * \mathrm{Rh}$ signals are evident) being formed, while at $\mathrm{pH}$ values greater than 6.0 , the $\mathrm{Cp} * \mathrm{Rh}-\mathrm{NAD}$ complex appears to be decomposing to $\mathrm{NAD}^{+}$hydrolysis products and the known $\left[\left(\mathrm{Cp}^{*} \mathrm{Rh}\right)_{2}(\mu-\mathrm{OH})_{3}\right](\mathrm{OTf}) .{ }^{10}$ Furthermore, the diagnostic chemical shifts that we have previously observed for all the enantiomeric/diastereomeric, cyclic trimer $[\mathrm{Cp} * \mathrm{Rh}(\mu-$ $\eta^{1}(\mathrm{~N} 1): \eta^{2}(\mathrm{~N} 6, \mathrm{~N} 7)-9$-substituted adeninato/5'-adenosinato/5'-adenosinato monophosphate methyl ester $]_{3}{ }^{3+}$ derivatives we synthesized are evident in the ${ }^{1} \mathrm{H}$ NMR 
spectrum at $\mathrm{pH} 6.0$ (Figure 7). Thus, the $\mathrm{H} 8$ proton $(8.28 \mathrm{ppm}$, spectrum a) of the adenine nucleus of free $\mathrm{NAD}^{+}$moves downfield $(\Delta \delta=0.35 \mathrm{ppm} ; 8.63,8.64 \mathrm{ppm}$, spectrum $\mathrm{b}$ ), while the free $\mathrm{NAD}^{+}$adenine $\mathrm{H} 2$ proton $(8.01 \mathrm{ppm}$, spectrum a) moves dramatically upfield ( $\Delta \delta=0.48 \mathrm{ppm} ; 7.54,7.52 \mathrm{ppm}$, spectrum b). These diagnostic ${ }^{1} \mathrm{H}$ NMR spectroscopy results allow us to unequivocally assign a cyclic trimer structure to complex 12; if complex 12 had a mononuclear structure, [Cp* Rh( $\eta^{2}(\mathrm{~N} 6, \mathrm{~N} 7)-9-(5 '-$ ribose pyrophosphate-5"-ribose-1"-nicotinamide)adeninato], the $\mathrm{H} 8$ and $\mathrm{H} 2$ protons would both be downfield shifted and no diastereomers would be evident, while the supramolecular, cyclic trimer structure of $\mathbf{1 2}$ provides a deshielding effect of $\mathrm{H} 8$ (downfield shift) and a shielding effect on $\mathrm{H} 2$ (upfield shift) with the presence of diastereomers (C3 symmetry). Interestingly, the nicotinamide protons also show two diastereomers with all pyridinium and ribose protons being doubled (Figure 7). To our knowledge, this was the first organometallic complex reported for $\mathrm{NAD}^{+} .{ }^{10}$
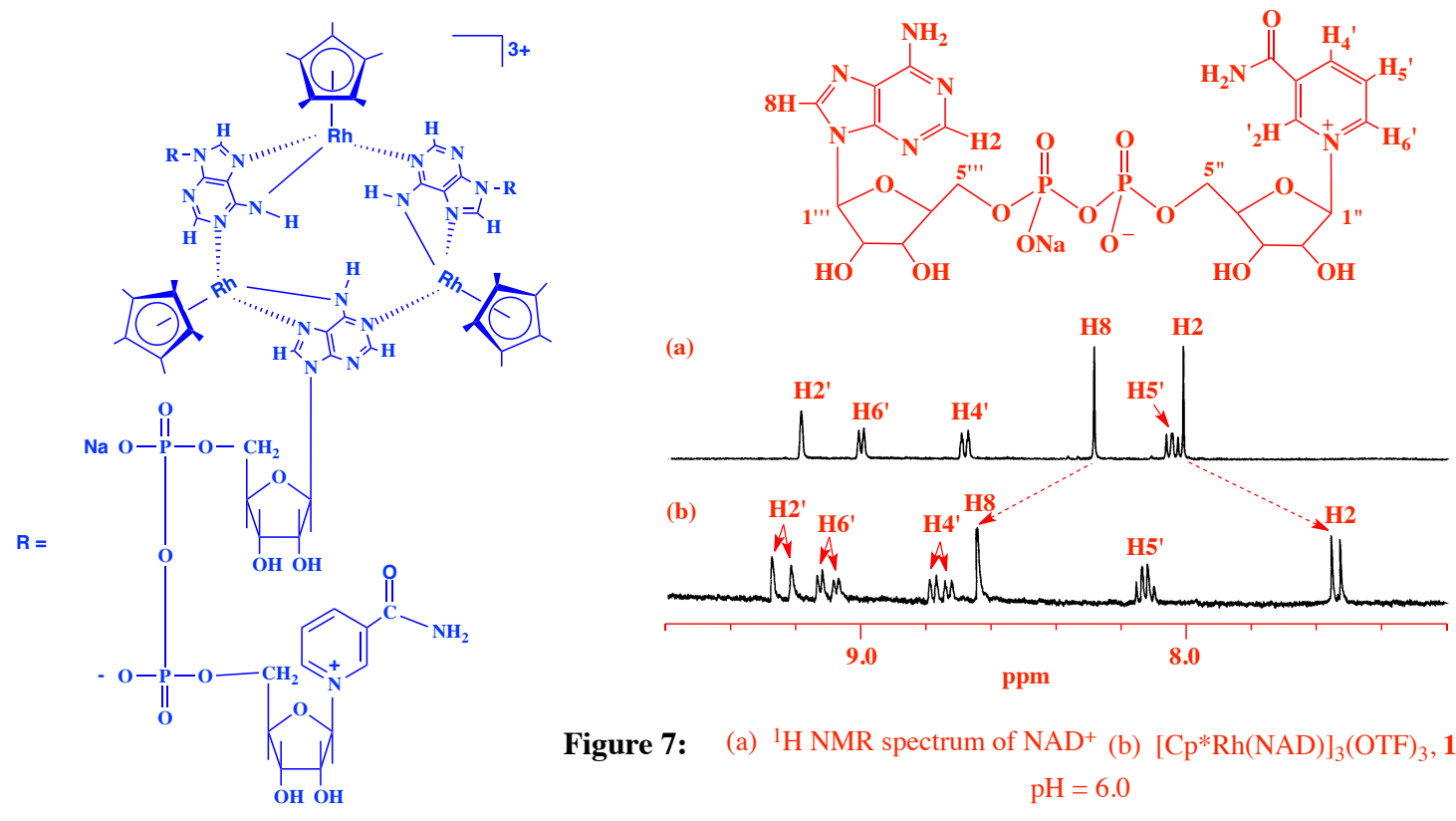

Figure 7: (a) ${ }^{1} \mathrm{H}$ NMR spectrum of $\mathrm{NAD}^{+}$(b) $[\mathrm{Cp} * \mathrm{Rh}(\mathrm{NAD})]_{3}(\mathrm{OTF})_{3}, 12$ $\mathrm{pH}=6.0$ 


\section{Molecular Recognition Studies with $\left[\mathrm{Cp}^{*} \mathbf{R h}\left(2^{\prime} \text {-deoxyadenosine }\right]_{3}(\mathrm{OTf})_{3}\right.$ as Host, with Biological Guests, in Water}

When we discovered the 9-substituted adenine, cyclic trimer structures, Figure 4, as an example, having $\mathrm{C} 3$ symmetry, we found that the $\mathrm{X}$-ray/computer generated molecular models conveyed a supramolecular, bowl structure to this potential host and thought about the possibilities of non-covalent $\pi-\pi$, hydrophobic, and subtle hydrogen bonding interactions with biologically important guest molecules. ${ }^{9}$ Indeed, this was the case and; moreover, we found that the $\left[\mathrm{Cp} * \mathrm{Rh}\left(2^{\prime} \text {-deoxyadenosine }\right)\right]_{3}(\mathrm{OTf})_{3}$ complex, 12, was the best host available (Figure 8).
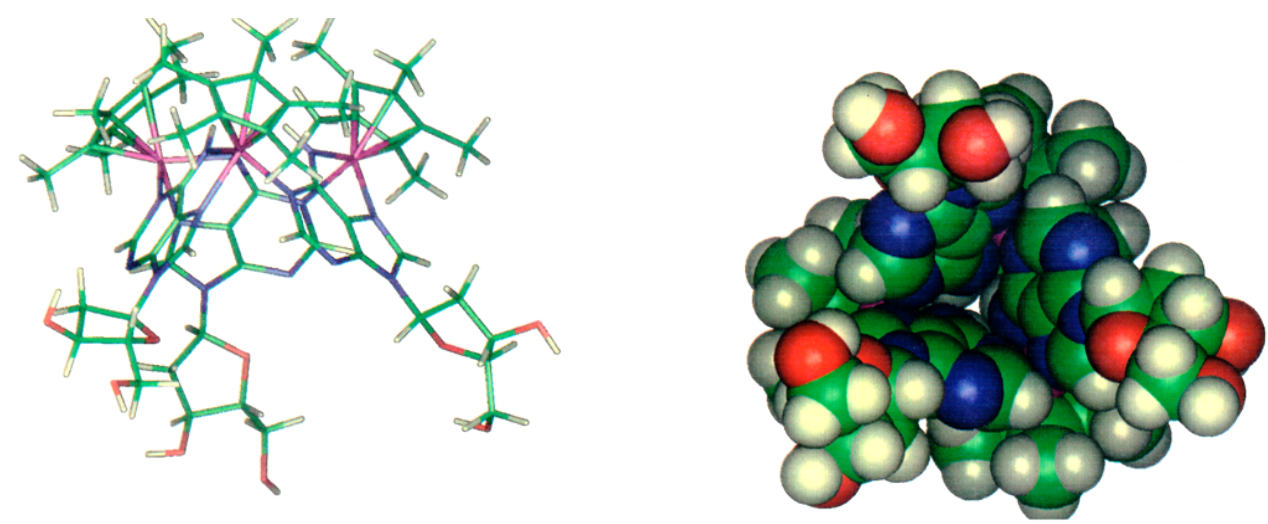

13

Figure 8. Shown on the left, the Dreiding model, while on the right, the CPK model of host, $\left[\mathrm{Cp} * \mathrm{Rh}\left(2^{\prime} \text {-deoxyadenosine }\right)\right]_{3}(\mathrm{OTF})_{3}, \mathbf{1 3}$.

Therefore, we studied a variety of guest aromatic and aliphatic amino acids, substituted aromatic carboxylic acids, and aliphatic carboxylic acids including examples such as L-phenylalanine, L-tryptophan (L-Trp), phenylacetic and cyclohexylacetic (CAA) acids were studied by ${ }^{1} \mathrm{H}$ NMR spectroscopy (association constants $\left[\mathrm{K}_{\mathrm{a}}\right]$ and free energies of complexation $\left[\Delta \mathrm{G}^{\mathrm{O}}\right]$ ) for their non-covalent interactions with the host, $[\mathrm{Cp} * \mathrm{Rh}(2 \text { '-deoxyadenosine })]_{3}(\mathrm{OTf})_{3}$. Thus, the aromatic groups interacted by a classical $\pi-\pi$ mechanism, while the aliphatic guests by classical hydrophobic interactions. The computer generated molecular recognition process of L-Trp with $\left[\mathrm{Cp} * \mathrm{Rh}\left(2^{\prime}-\right.\right.$ deoxyadenosine $)]_{3}(\mathrm{OTf})_{3}, \mathbf{1 3}$, is shown in the energy minimized, space-filling host and the docking of L-Trp (Figure 9). ${ }^{11}$ These overall results suggest that the molecular recognition of $\mathbf{L}-\mathbf{T r p}$ with $\left[\mathrm{Cp}^{*} \mathrm{Rh}\left(2^{\prime} \text {-deoxyadenosine }\right)\right]_{3}(\mathrm{OTf})_{3}$ can be described in a way that places the L-Trp aromatic rings inside of the host cavity with the aromatic plane, or more specifically, the line which bisects the C-H(a) and C-H(a') bonds parallel to the $\mathrm{C} 3$ axis of the host. ${ }^{11}$ 

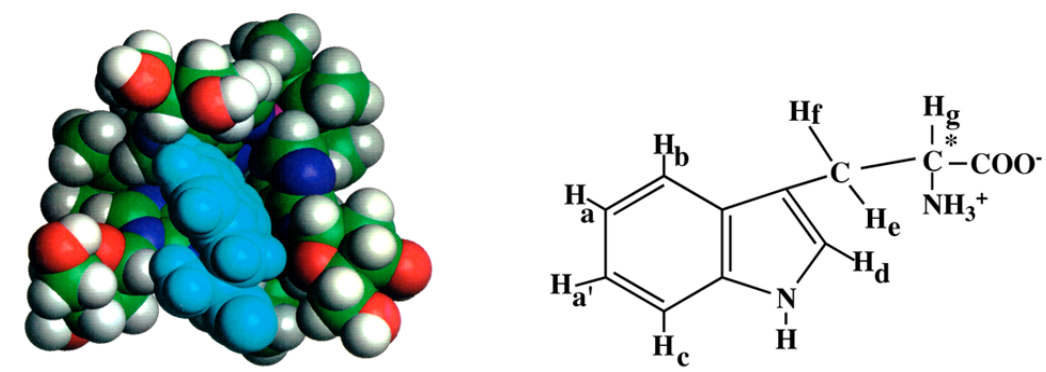

Figure 9: Docking Experiment with Host, $[\mathrm{Cp} * \mathrm{Rh}(2 \text { '-deoxyadenosine })]_{3}(\mathrm{OTf})_{3}$, and Guest, L-Tryptophan, (right)

\section{Biomimics of $\mathrm{NAD}^{+} / \mathrm{NADH}$, and Co-factor Regeneration with $[\mathrm{Cp} * \mathbf{R h}(\mathrm{bpy}) \mathrm{H}](\mathrm{OTf}):$ Enzyme Compatibility with Organometallic Chemistry}

Furthermore, we were interested in understanding the mechanism of an important co-factor regeneration reaction that regioselectively reduced natural $\mathrm{NAD}^{+}$to NADH using in situ formed [Cp*Rh(bpy)H](OTf). ${ }^{12}$ However, we decided to simplify the natural $\mathrm{NAD}^{+}$structure by using a biomimic that stripped the ribose, pyrophosphate, and adenosine groups from the natural $\mathrm{NAD}^{+}$structure, while adding a benzyl group, $\mathrm{N}$-benzylnicotinamide triflate, $\mathbf{1 3}$. We also synthesized a NAD ${ }^{+}$biomimic that contained a ribose with a methyl ester phosphate group, $\mathrm{N}$-ribose phosphate (methyl ester) nicotinamide, $\mathbf{1 4}$. We then found that the biomimetic models were also regioselectively reduced by in situ formed [Cp* $\mathrm{Rh}(\mathrm{bpy}) \mathrm{H}](\mathrm{OTf})$ to form the 1,4-dihydro, NADH, biomimics, via the following mechanism (Figure 10). ${ }^{12}$<smiles>NC(=O)c1ccc[n+](Cc2ccccc2)c1</smiles>

13

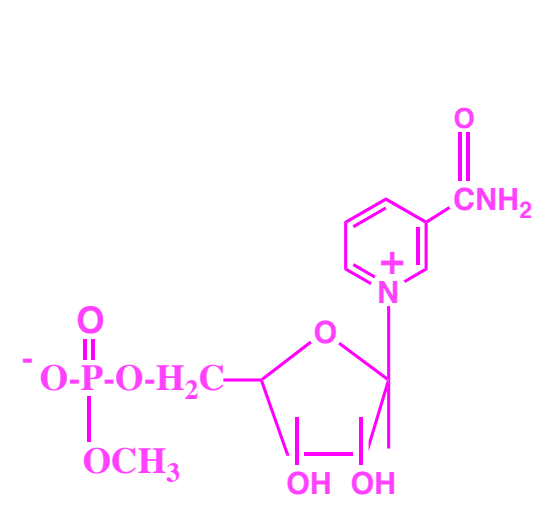

14<smiles>N#[N+]OP(=O)(OP(=O)([O-])OCC1OC(n2cnc3c(N)ncnc32)C(O)C1O)OP(=O)([O-])OCC1OC([n+]2cccc(C(N)=O)c2)C(O)C1O</smiles>

$\mathrm{NAD}^{+}$
14 


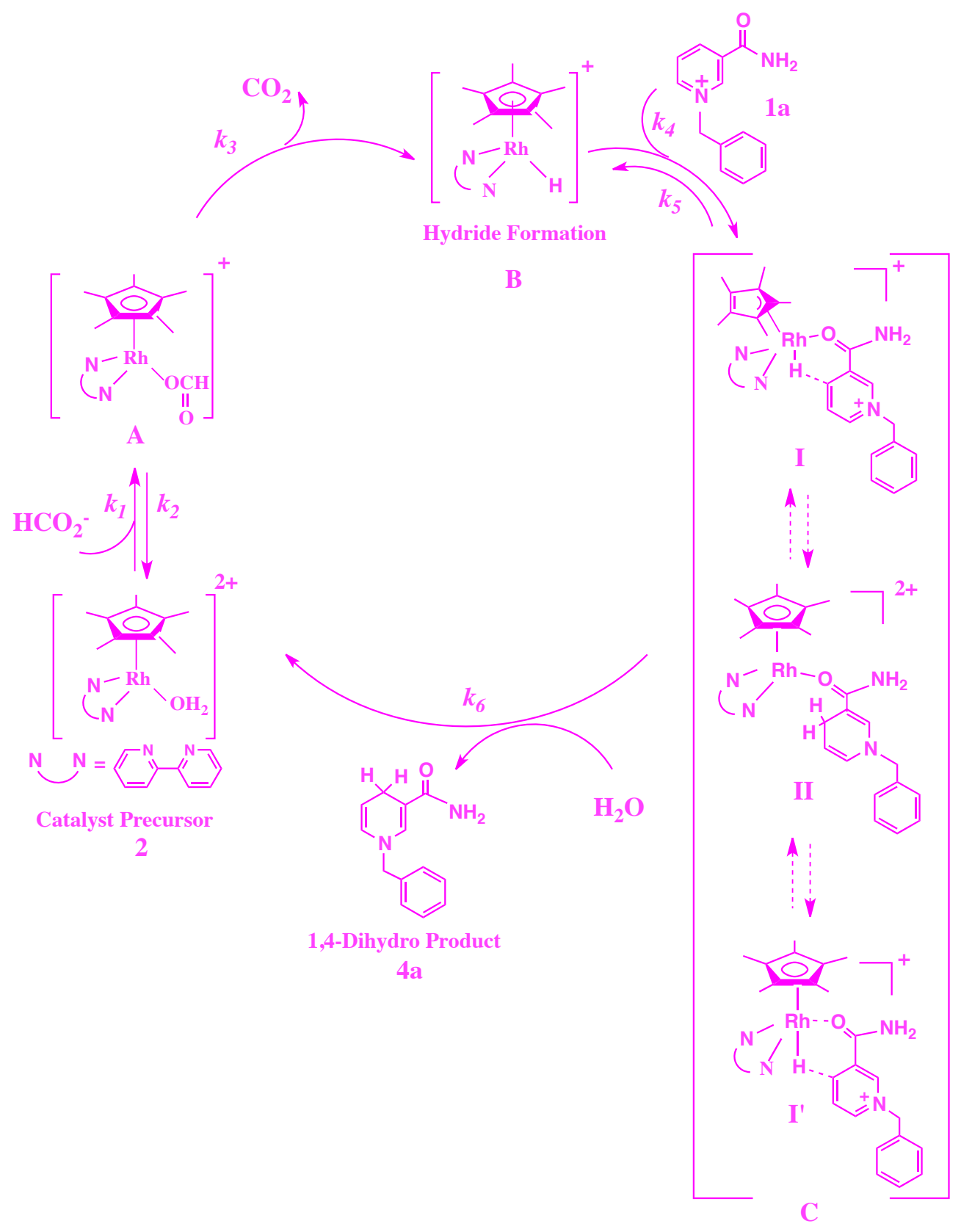

Figure 10: Regioselective Reduction Mechanism of $\mathrm{NAD}^{+}$Biomimics with in situ formed [Cp*Rh(bpy)H](OTf). 
In a totally serendipitous manner, we decided to utilize the biomimetic models of $\mathrm{NAD}^{+}$with HLADH enzymes, in tandem with [Cp*Rh(bpy)H](OTf) co-factor regeneration. We were totally amazed that an NADH dependent enzyme, HLADH, recognized the NADH biomimics to convert achiral ketones to chiral alcohols; in control experiments, these biomimics provided similar results as the natural NADH, both in yield and enantioselectivity (Scheme 2)..$^{13}$

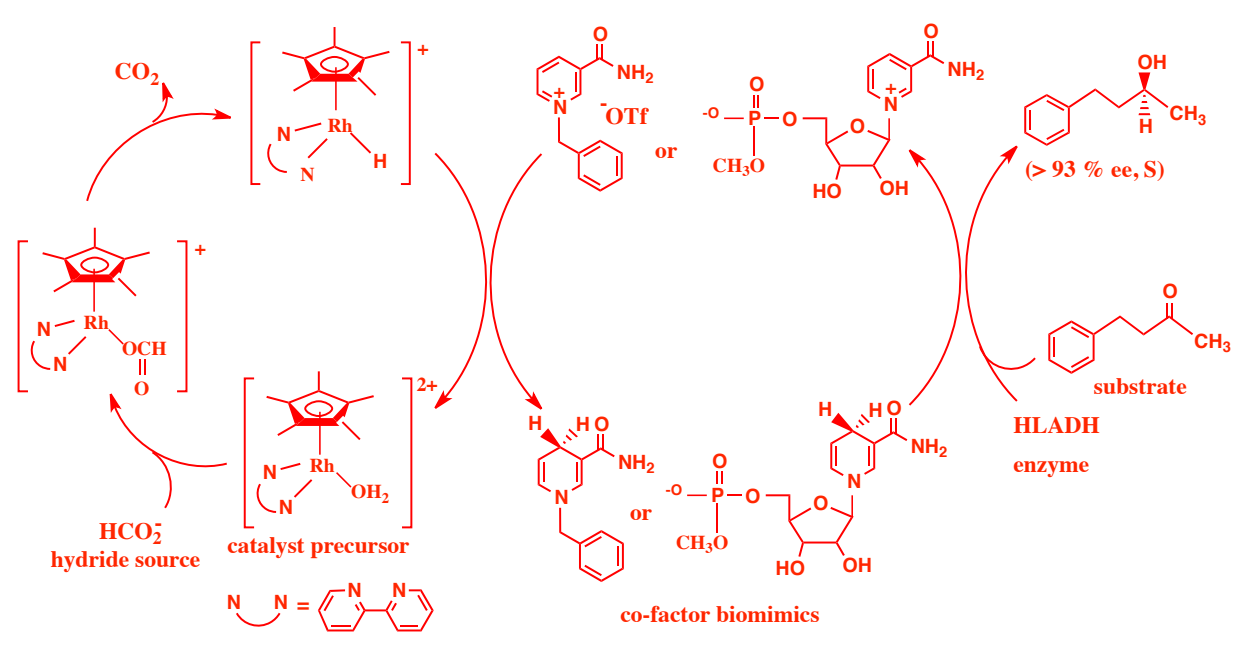

Scheme 2: Tandem Catalysis, Co-factor Regeneration, and Chiral Synthesis using $\mathrm{HLADH}$ with Biomimetic $\mathrm{NAD}^{+} / \mathrm{NADH}$ Co-factors

This unprecedented tandem catalysis result was also observed with monooxyenases, such as P450 BM-3 and P450 CAM, and was further enhanced by utilizing protein engineering (Scheme 3 ) to increase the molecular recognition process of the NADH biomimetic co-factor and the FAD containing electron transfer protein. ${ }^{14}$ What these results signified was that organometallic chemistry and enzymology have been shown to be complementary, and that $[\mathrm{Cp} * \mathrm{Rh}(\mathrm{bpy}) \mathrm{H}](\mathrm{OTf})$ co-factor regeneration was not compromised by enzyme interactions. This was also the case utilizing a monoxygenase, $\mathrm{HbpA}$, a catecholase that converts phenols to catechols. ${ }^{15}$

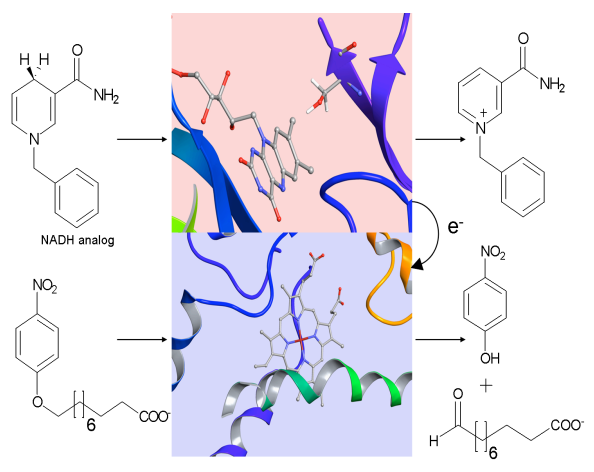

Scheme 3. P450 BM3 Double Mutant: Trp to Ser, and Arg to Asp, via Site Directed Mutagenesis. 


\section{Cp*Rh-Hydroxytamoxifen Complexes: Their Synthesis, Biological Activity, and Molecular Docking to the Isoforms of the Estrogen Receptor, ER $\alpha$ and ER $\beta$.}

Another topic we have pursued was focused on the organometallic pharmaceutical discipline. The drug discovery paradigm was dramatically changed with the introduction of organometallic pharmaceuticals, as complexes that were more stable kinetically and thermodynamically, and whose properties could be adjusted to be hydrophobic for cell penetration, and hydrophilic inside the cell. ${ }^{16 a-n}$ Our approach was to study the chemistry of the cis and trans metabolites of tamoxifen, hydroxytamoxifens, 15 and 16, with $\mathrm{Cp} * \mathrm{Rh}$ solvato complexes, to identify novel chemistry with this multidentate ligand, and hopefully, provide evidence for biological activity. ${ }^{17}$

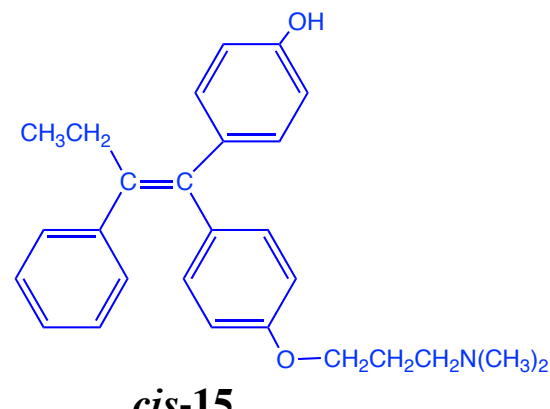

cis-15

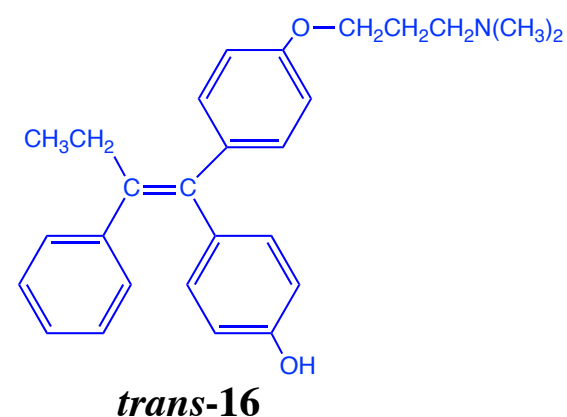

trans-16

Our initial thought was to do all the hydroxytamoxifen ligand experiments in water; however, we quickly clarified an important point, that ligands, cis-15 and trans16, were not soluble in water. The initial studies were accomplished via ${ }^{1} \mathrm{H}$ NMR in $\mathrm{CH}_{3} \mathrm{OH}-\mathrm{d}_{4}$. This provided evidence that the kinetic products were $\eta^{1}-\mathrm{N}-\mathrm{Cp} * \mathrm{Rh}$ complexes, [1-butenyl-2-phenyl-1-(p-phenol)-1'-p-phenyl-(oxotrimethylene-3dimethylamino $)\left(\eta^{1}-\mathrm{N}-\eta^{5}\right.$-pentamethylcyclopentadienylrhodium $)\left(\eta^{1}-\mathrm{O}-\right.$ $\left.\left(\mathrm{CH}_{3} \mathrm{OH}\right)(\mathrm{OTf})\right](\mathrm{OTf})$, cis-17 $\left(\mathrm{CH}_{3} \mathrm{OH}\right)$ and trans-18 $\left(\mathrm{CH}_{3} \mathrm{OH}\right){ }^{17}$

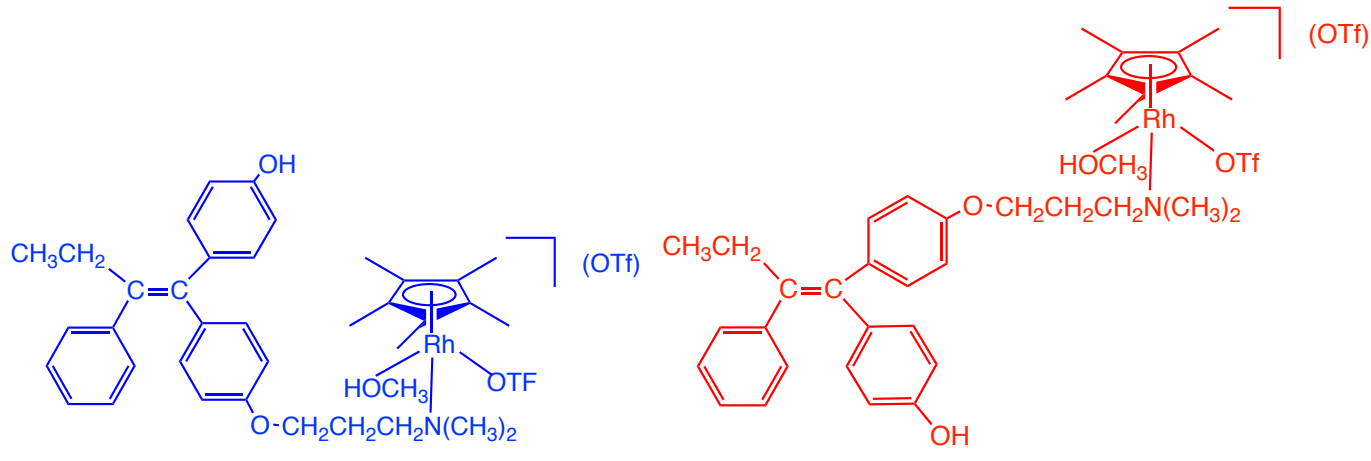

cis-17( $\left.\mathrm{CH}_{3} \mathrm{OH}\right)$

trans-18( $\left(\mathrm{CH}_{3} \mathrm{OH}\right)$ 
When we heated these $\eta^{1}-\mathrm{N}-\mathrm{Cp} * \mathrm{Rh}$ complexes, $\boldsymbol{c i s}-\mathbf{1 7}\left(\mathbf{C H}_{3} \mathbf{O H}\right)$ and trans$\mathbf{1 8}\left(\mathrm{CH}_{3} \mathrm{OH}\right)$, individually to $60{ }^{\circ} \mathrm{C}$, we observed a novel and unprecedented $\mathrm{N}-\pi$ rearrangement that gave, after in-depth HMQC, HMBC, COSY, and NOESY correlation NMR studies, the cis or trans-[1-butenyl-2-phenyl-1- $\left(\eta^{5}\right.$-pentamethylcyclopentadienyl$\eta^{6}$-p-phenol)rhodium)-1'-p-phenyl-(oxotrimethylene-3-dimethylamino)](OTf) ${ }_{2}$, respectively, complex $[\text { cis-19] }]^{2+}$ or $[\text { trans-20 }]^{2+17}$

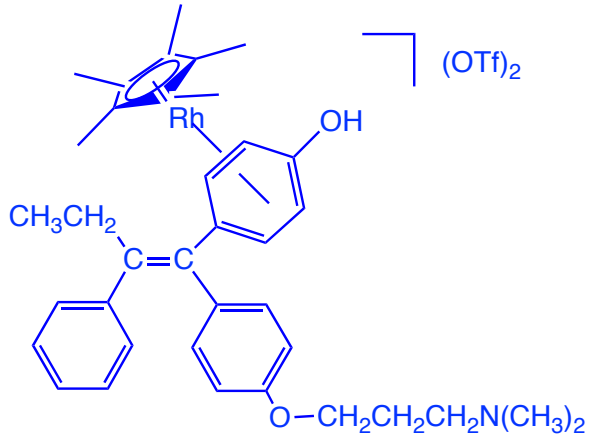

$\left[\right.$ cis-19] ${ }^{2+}$

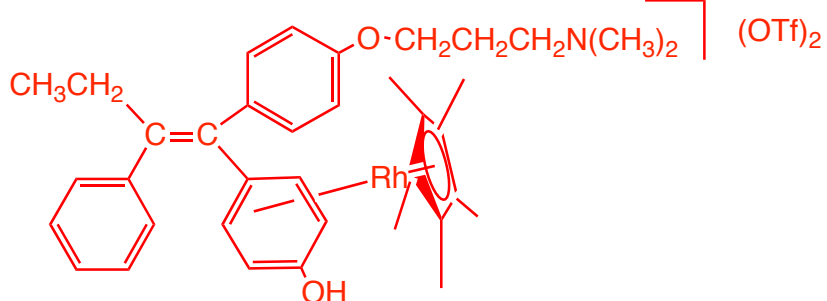

$\left[\right.$ trans-20 ${ }^{2+}$

Moreover, we found that starting with $\operatorname{cis}-\mathbf{1 7}\left(\mathbf{C H}_{3} \mathbf{O H}\right)$, we observed the two $\eta^{6}-\mathrm{Cp} * \mathrm{Rh}$ complexes, [cis-19] ${ }^{2+}$ and [trans-20 $]^{2+}$, via NMR analysis of the new dimethylamino signals that appeared at 2.97 and $2.95 \mathrm{ppm}$; respectively, in the ratio of $\sim 5: 1$, after $17 \mathrm{~h}$ of heating at $50{ }^{\circ} \mathrm{C}$ in $\mathrm{CD}_{3} \mathrm{OD}-\mathrm{d}_{4}$, reflecting the isomerization of cis-17( $\left.\mathrm{CH}_{3} \mathrm{OH}\right)$ to trans-18(CH$\left(\mathrm{CH}_{3} \mathrm{OH}\right)$ prior to the $\mathrm{N}-\pi$ rearrangement, as stated above. This propensity for the hydroxytamoxifen compounds, and its derivatives, to isomerize in organic solvents, has been previously studied by ${ }^{1} \mathrm{H} \mathrm{NMR}$; for example, cis-ferrocifen, 3 , in DMSO- $\mathrm{d}_{6}$ and benzene- $\mathrm{d}_{6}$, showed no trans isomer after one day at room temperature, while in $\mathrm{CDCl}_{3}$ and acetone- $\mathrm{d}_{6}$, there was a 1:1 and 3:7 cis/trans ratio, respectively.

Interestingly, there was a dramatic solvent effect on the rate of the $\mathrm{N}-\pi$ rearrangement. ${ }^{17}$ We discovered that in $\mathrm{CH}_{2} \mathrm{Cl}_{2}$ the $\mathrm{N}-\pi$ rearrangement, starting with the in situ formed $\eta^{1}-\mathrm{N}$ complex, was completed in $15 \mathrm{~h}$ at $22^{\circ} \mathrm{C}$ for both cis-21(OTf) and trans-22(OTf) to either [cis19] ${ }^{2+}$ or [trans-20] ${ }^{2+}$ (eq. 3), while in $\mathrm{CH}_{3} \mathrm{OH}$ no reaction occurred at $22{ }^{\circ} \mathrm{C}$; under these mild reaction conditions in $\mathrm{CH}_{2} \mathrm{Cl}_{2}$, neither cis-21(OTf) nor trans-22(OTf) was isomerized to a cis and trans mixture of both starting complexes. 

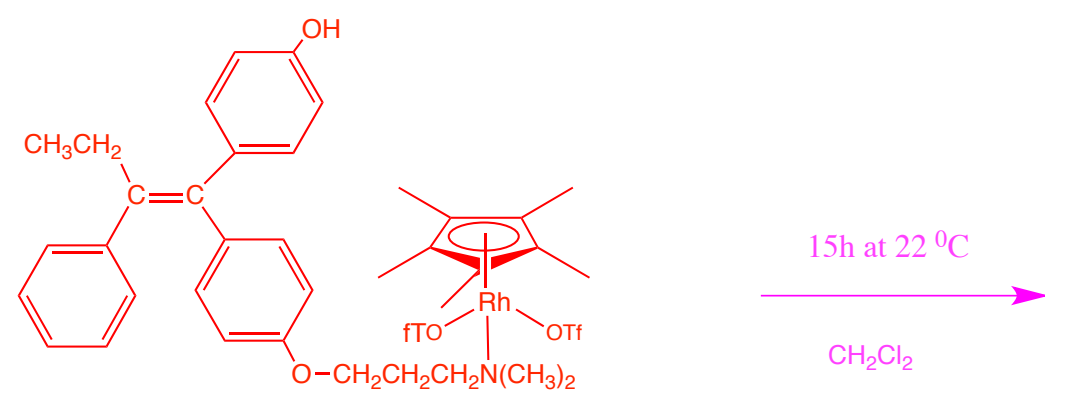

cis 21(OTf)

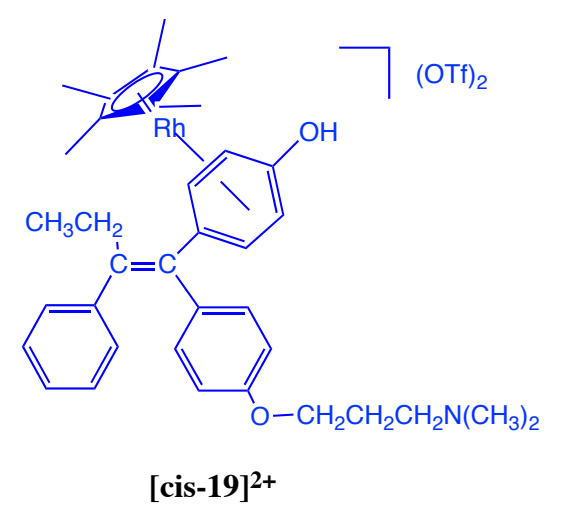

\section{The Mechanism of the $N-\pi$ Rearrangement}

The intramolecular and chemoselective $N-\pi$ rearrangement involved both the monocationic $\mathrm{Cp}^{*} \mathrm{Rh}-\mathrm{N}$ complex, and the inner sphere $\mathrm{Cp} * \mathrm{Rh}-\mathrm{OTf}$ bond dissociations, as highly important steps, in this reaction mechanism. The geometries of the complexes that existed in $\mathrm{CH}_{2} \mathrm{Cl}_{2}$ and $\mathrm{CH}_{3} \mathrm{OH}$ solutions, including their recently derived DFT calculated energies, allowed us to determine the lowest energy pathway for this novel transformation. ${ }^{17,18}$ Thus, the most plausible reaction mechanism for the $\mathrm{N}-\pi$ rearrangement is shown in Scheme 4. 

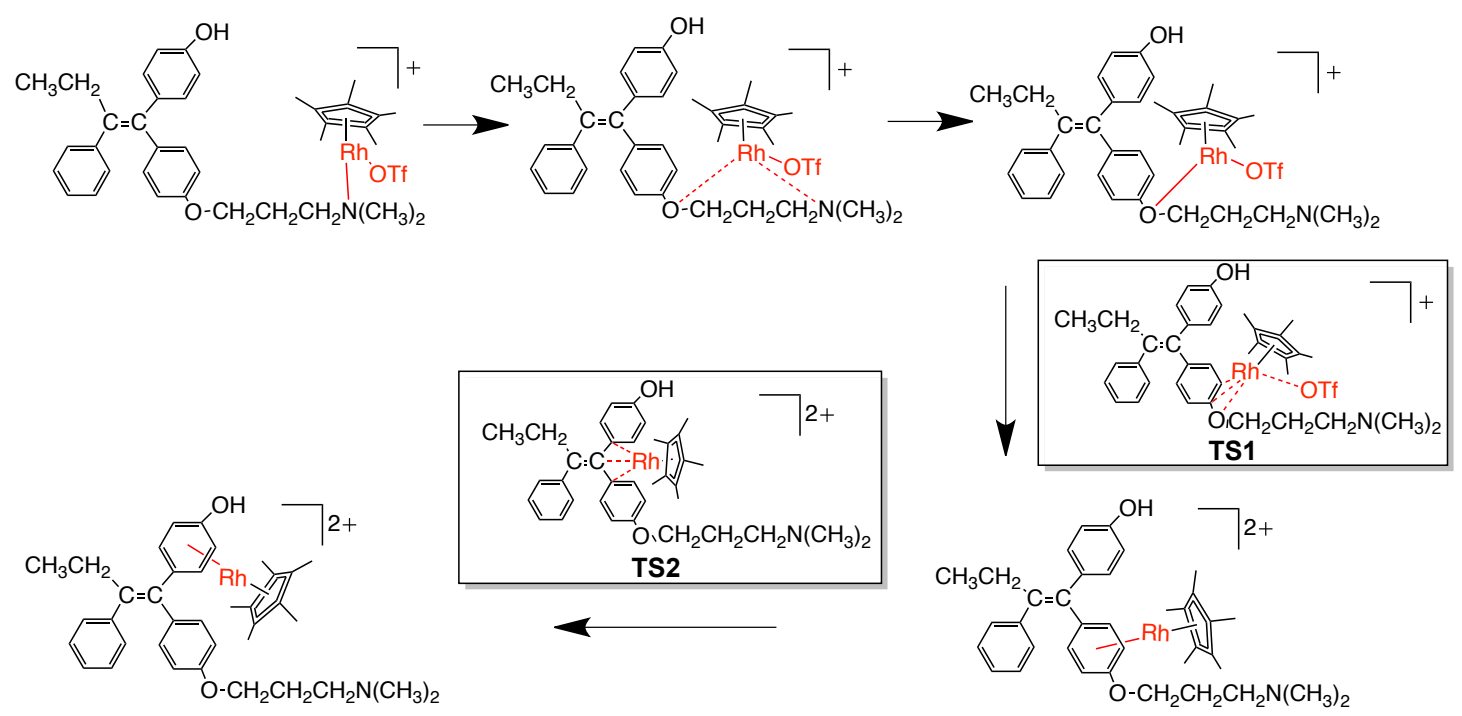

Scheme 4. Plausible reaction mechanism for the $N-\pi$ rearrangement. Outer sphere counterions are omitted for clarity. TS1 and TS2 are the calculated transition states. ${ }^{14}$

\section{Relative Binding Affinities of Complexes $\left[\right.$ cis-19] ${ }^{2+}$ and $\left[\right.$ trans-20] ${ }^{2+}$ for the ER $\alpha$ and ER $\beta$ Estrogen Receptors, and Growth Inhibition Properties of $[\text { cis-19] }]^{2+}$ with Breast Cancer Cell Lines}

Tamoxifen was found to be an antagonist breast cancer drug, that competitively inhibited the female hormone, estradiol, from binding to the hormone dependent ER $\alpha$ estrogen receptor, as one important aspect for anti-cancer activity. Therefore, in order to determine the biological parameters of the water soluble $\left[\right.$ cis-199 ${ }^{2+}$ and $\left[\right.$ trans-20] ${ }^{2+}$ complexes, the relative binding affinities (RBA) of these complexes for the two isoforms of the estrogen receptors (ER $\alpha$ and $E R \beta, 4{ }^{\circ} \mathrm{C}, 3 \mathrm{~h}$ ) were determined using a competition experiment with $\left[{ }^{3} \mathrm{H}\right]$-estradiol, and provided values of $4.7 \%$ and $1 \%$, respectively. ${ }^{12}$ Thus, it clearly showed a significant difference between the two geometrical isomers, $\left[\right.$ cis-19] ${ }^{2+}$ and $[\text { trans-20 }]^{2+}$, which suggested differences in the binding conformation at the estrogen receptor. For comparison, Ferrocifen has an RBA of $11.5 \%\left(4{ }^{\circ} \mathrm{C}, 3 \mathrm{~h}\right) .{ }^{12}$ Clearly, $\left[\right.$ cis-19] ${ }^{2+}$ was found to be moderately competitive with estradiol for binding to the $\mathrm{ER} \alpha$ receptor. Both compounds were recognized by the two isoforms of the estrogen receptor; however, the RBA values for the $c i s$ isomer, $[c i s-19]^{2+}$, on both isoforms of the receptor were significantly higher than those found for the trans isomer, $\left[\right.$ trans-20 ${ }^{2+}{ }^{27,18}$

The effect of the complex, $[\text { cis-19 }]^{2+}$, on the growth of cancer cells has been tested on two breast cancer cell lines, MCF-7 and MDA-MB-231, which are respectively, hormone dependent and hormone independent. The $[\boldsymbol{c i s}-19]^{2+}$ complex showed a growth inhibition, on these two cell lines with $\mathrm{IC}_{50}$ values in the range of $1.25-11 \mu \mathrm{M}$. Thus, the $[\text { cis-19 }]^{2+}$ isomer, which had a moderate RBA value, showed a anti-estrogenic effect towards the MCF7 breast cancer cells, $\mathrm{IC}_{50}$ of $1.25 \mu \mathrm{M}$, and a modest anti-proliferative effect towards the hormone independent MDA-MB-231 breast cancer cells, with an $\mathrm{IC}_{50}$ of $11 \mu \mathrm{M} .^{17}$ 


\section{Computer Docking Studies of $[\text { cis-19] }]^{2+}$ at the Isoforms of the Estrogen Receptor, Hormone Dependent, ER $\alpha$, and Hormone Independent, ERß, Including Thermodynamic Values of Binding}

Since one important aspect of the bioactivity of all these potential organic, inorganic, and organometallic breast cancer drugs has been their action as an antagonist in competition with the female hormone, estradiol, we were interested in the binding modes of [cis19] ${ }^{2+}$, the growth inhibitor that was analyzed against the MCF7 and MDA-MB-231 cell lines, $\mathrm{ER} \alpha(+), \mathrm{IC}_{50}=1.25 \mu \mathrm{M}$, and $\mathrm{ER} \alpha(-), \mathrm{IC}_{50}=11 \mu \mathrm{M}$, respectively. Cartoon representations of the predicted $3 \mathrm{D}$ structures of $\left[\right.$ cis-19] ${ }^{2+}$, were obtained using 3ERD and 2FSZ PDB structures as initial models of the ER $\alpha$ and ER $\beta$ receptor binding sites, respectively, and are shown in Figure 11, along with the binding energies. The [cis19] ${ }^{2+}$ complex was bound in the pocket formed by helices H3, H4, H5, and H12, in a manner similar to that described before for other drugs. ${ }^{17,18}$

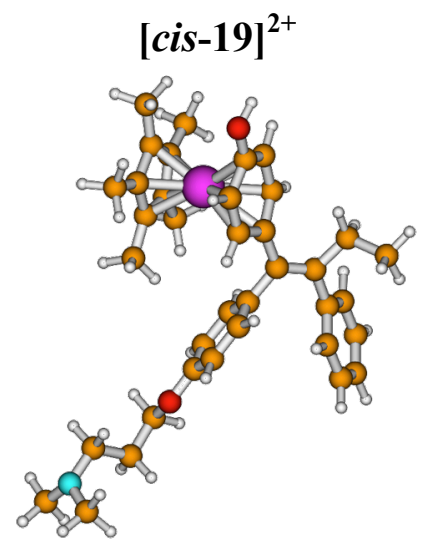

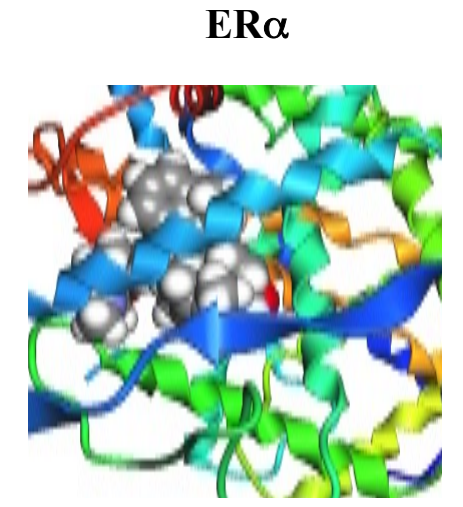

BE -18.37

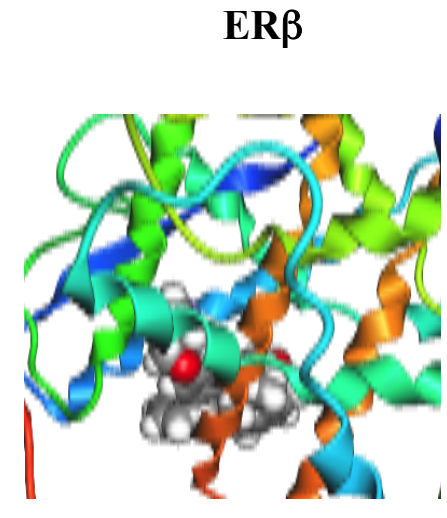

BE -17.07

Figure 11. Cartoon representations of the ER $\alpha$ and $E R \beta$ receptor binding sites with docked $\left[\right.$ cis-19] ${ }^{2+}$ (left), together with the corresponding calculated binding energies $(\mathrm{kcal} / \mathrm{mol})$. The docked guests are shown in the $\mathrm{CPK}$ rendering mode.

Analysis of the $\left[\right.$ cis-19] ${ }^{2+}$ interactions with the ER $\alpha$ and ER $\beta$ receptor binding sites demonstrated that the main contribution to the host-guest interaction energy came from van der Waal and electrostatic interactions of the dicationic complex with the surrounding amino acids. Interaction of the phenol hydroxyl group, and the ether oxygen groups of cis-6 with $\mathrm{O}$ atoms of the surrounding amino acids, has generally been shown to have repulsive characteristics. More importantly, it also could possibly be the compact configuration adopted by the guest, $\left[\right.$ cis-19] ${ }^{2+}$, within the ER $\alpha$ host binding site, such that the electrophilic $\mathrm{H}$ atom of the phenol group was not readily available for non-covalent bonding regimes. ${ }^{17,18}$ 


\section{Reactions of $\left[\mathrm{Cp}^{*} \mathrm{Rh}\left(\mathrm{H}_{2} \mathrm{O}\right)_{3}\right](\mathrm{OTf})_{2}$ with G-Protein Coupled Receptor Peptides: Synthesis, 2D NMR Structures, and the Biological Consequences}

The Bioorganometallic Chemistry discipline has clearly demonstrated that organometallic chemistry is compatible, at the interface, with biology. One current topic, the bioconjugation of important peptides to organometallic complexes, has been studied extensively. ${ }^{19}$ In general, the organometallic complexes have been bioconjugated terminally, to either the free amino or carboxyl groups of the designated peptide, which could potentially have adverse affects on their bioactivity, while the majority of these bioconjugation reactions were conducted in organic solvents.

The phenol side chain of tyrosine-containing peptides has been shown to be a potential component for molecular recognition, as well as biological activity, with certain G-protein-coupled receptors (GPCRs). Moreover, GPCRs have been shown to influence the physiological responses to hormones, neurotransmitters, and environmental stimulants; and therefore, have importance as therapeutic targets for a wide spectrum of critical diseases. ${ }^{20}$ For example, tyrosine kinases have been involved in autoimmune diseases and cancer, while tyrosine residues, in proteins, were shown to be crucial in some electron-transfer pathways, or at the active sites of some enzymes.

Surprisingly, the tyrosine residue of peptides had not been previously considered as a site of reactivity with organometallic reagents, in competition with other aromatic amino acid residues. Therefore, we discovered a facile, chemoselective bioconjugation of important tyrosine amino acid components of GPCR peptides, in water, at room temperature, as a function of $\mathrm{pH}$, by utilizing the air and water stable organometallic aqua complex, $\left[\mathrm{Cp} * \mathrm{Rh}\left(\mathrm{H}_{2} \mathrm{O}\right)_{3}\right](\mathrm{OTf})_{2}$. The important tyrosine-containing GPCR peptides that were used to demonstrate this chemoselective bioconjugation technique are shown in the Chart 1 , and they include, $\left[\operatorname{Tyr}^{1}\right]$-leu-enkephalin, $\left[\operatorname{Tyr}^{4}\right]$-neurotensin(8-13), and $\left[\mathrm{Tyr}^{3}\right]$-octreotide, with the tyrosine residue being a potential molecular recognition component for binding to their respective receptor sites; the message-address paradigm. 


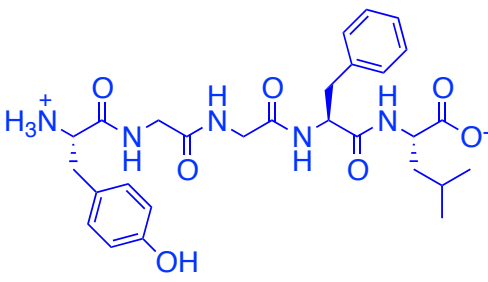

[Tyr $\left.{ }^{1}\right]$-Leu-enkephalin

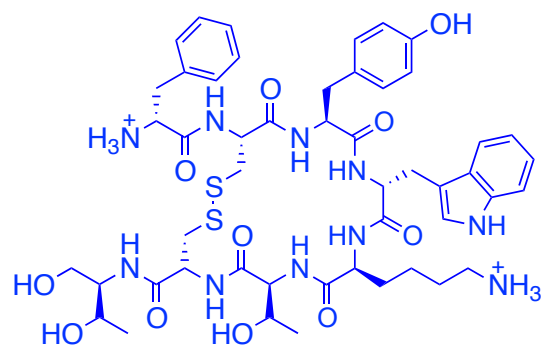

$\left[\mathrm{Tyr}^{3}\right]$-Octreotide

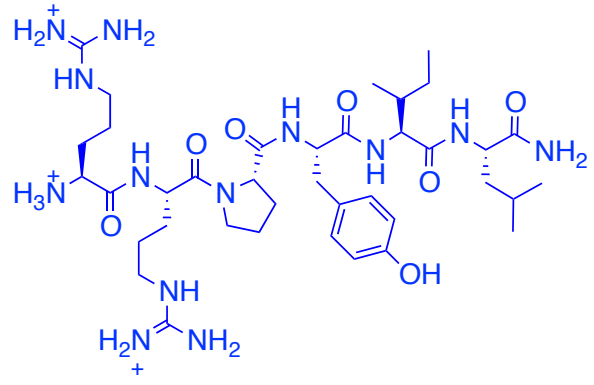

$\left[\right.$ Tyr $\left.^{4}\right]-$ Neurotensin (8-13)

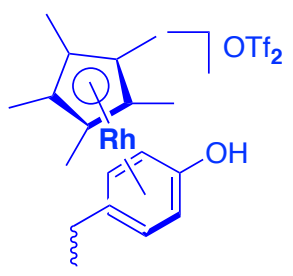

$\eta^{6}-\mathrm{Cp}{ }^{*} \mathrm{Rh}-\mathrm{Ty}$ rosine Complexes of Peptides

Chart 1: GPCR Peptides and their $\left[\left(\eta^{6}-\mathrm{Cp} * \mathrm{Rh}-\mathrm{Tyr}^{\#}\right)-\mathrm{GPCR} \text { Peptide }\right]^{2+}$ Complexes

A representative reaction, with 2D NMR structures of both the GPCR peptide, $\left[\mathrm{Tyr}^{3}\right]$-octreotide, and its $\left[\left(\eta 6-\mathrm{Cp} * \mathrm{Rh}^{-} \mathrm{Tyr}^{3}\right) \text {-octreotide }\right]^{2+}$ complex, are shown in Figure 12 , along with their binding constants to the octreotide somatostatin receptor.

Furthermore, both adopted the backbone canonical $\beta$-turn structure at the well-defined $\mathrm{D}_{\text {Trp }}{ }^{4}$-Lys ${ }^{5}$-dipeptide, although their pharmacophore conformations were found to be dramatically different. In the 2D NMR structure of $\left[\left(\eta^{6}-\mathrm{Cp} * \mathrm{Rh}-\mathrm{Tyr}^{3}\right) \text {-octreotide }\right]^{2+}$, the $\mathrm{Cp}$ *Rh group was coordinated to the side chain of $\mathrm{Tyr}^{3}$ in an $\eta^{6}$ bonding mode, and consequently, pushed the side chain of the ${ }^{\mathrm{D}} \operatorname{Trp}^{4}$ residue away, and rotated toward the direction of the Lys ${ }^{5}$ residue (Figures 12). This resulted in the Lys ${ }^{5}$ residue being flipped to the other side of the pharmacophore (Figure 12). The overall structural similarities of the peptide backbones, demonstrated by 2D NMR, were also confirmed by the CD spectra of [ $\mathrm{Tyr}^{3}$ ]-octreotide with minima at 196 and $218 \mathrm{~nm}$, and a maximum at $230 \mathrm{~nm}$, corresponding to an anti- parallel pleated $\beta$-sheet and type II' $\beta$-turn, while $\left[\left(\eta^{6}-\mathrm{Cp} * \mathrm{Rh}-\mathrm{Tyr}^{3}\right) \text {-octreotide }\right]^{2+}$ had two less intense, and slightly red-shifted minima at 198 and $221 \mathrm{~nm}$, and no maximum around $230 \mathrm{~nm} .^{20}$ 

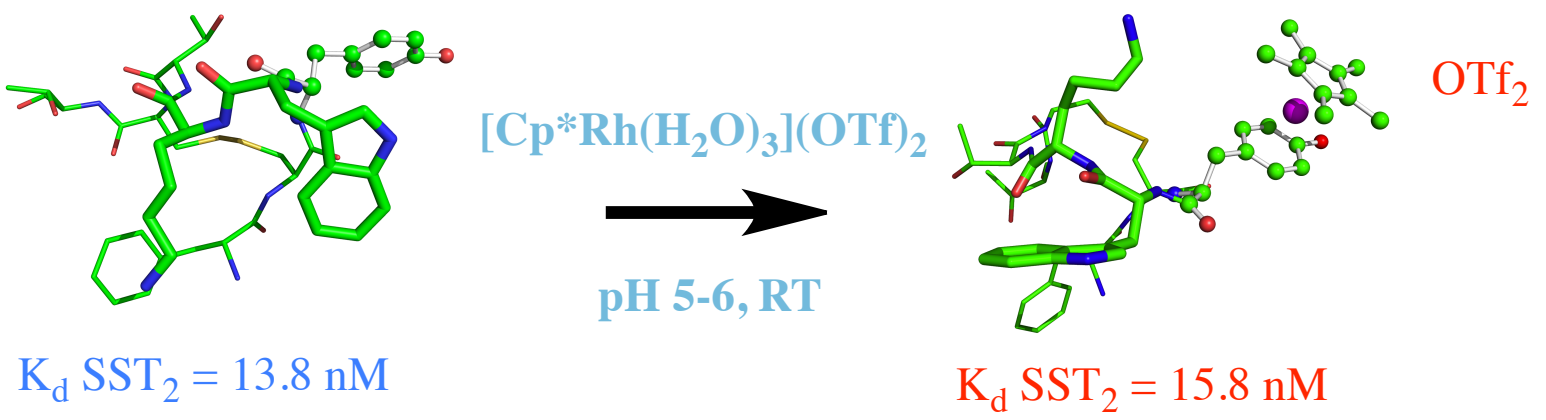

Figure 12. 2D NMR Structures of $\left[\mathrm{Tyr}^{3}\right]$-octreotide (left), and the $\left[\left(\eta^{6}-\mathrm{Cp} * \mathrm{Rh}-\mathrm{Tyr}^{3}\right)\right.$ octreotide $]^{2+}$ complex (right), with reaction conditions, and binding constants to the Octreotide Somatostatin Receptor.

The plausible reason for the high chemoselectivity of the $\left[\eta^{6}-\mathrm{Cp} * \mathrm{Rh}-\mathrm{tyrosine}\right]^{2+}$ product with all three peptides, at $\mathrm{pH} \sim 5-6$, might be predicated on the dramatic lowering of the $\mathrm{pK}_{\mathrm{a}}$ of the phenol hydrogen as the $\eta^{2} / \eta^{4}-\mathrm{Cp} * \mathrm{Rh}$-tyrosine intermediates transition to the final $\eta^{6}-\mathrm{Cp} * \mathrm{Rh}$-tyrosine complex; i.e., the back donation into the Rh d-orbitals from increased electron density into the phenol aromatic ring as the $\mathrm{pH}$ was raised from $\sim 3$ to $\sim 5-6$, provided a driving force for higher reactivity. Moreover, the $\mathrm{pH}$ also appears to have controlled the lack of reactivity of all the amino groups via protonation.

The biological consequences of the $\eta^{6}-\mathrm{Cp} * \mathrm{Rh}$ modification of tyrosinecontaining peptides, were of interest; therefore, our initial bioassay studies were conducted with $\left[\left(\eta^{6}-\mathrm{Cp} * \mathrm{Rh}^{-T y r^{1}}\right)\right.$-leu-enkephalin $](\mathrm{OTf})_{2}$. The $\mathrm{EC}_{50}$ receptor binding value for the $\left[\mathrm{Tyr}^{1}\right]$-leu-enkephalinan opioid receptor peptide, and that for $\left[\left(\eta^{6}-\mathrm{Cp} * \mathrm{Rh}\right.\right.$ $\operatorname{Tyr}^{1}$ )-leu-enkephalin](OTf) 2 , at the $\mu$-opioid receptor $(\mu$-OR), or $\partial$-opioid receptor $(\partial$ OR), can be found in Table 1 . It was shown that $\left[\left(\eta^{6}-\mathrm{Cp} * \mathrm{Rh}-\mathrm{Tyr}{ }^{1}\right)\right]$-leuenkephalin](OTf $)_{2}$, was an agonist, with $\mathrm{nM}$ potency, on cells expressing $\mu$-OR or $\partial-\mathrm{OR}$ alone, as well as on cells co-expressing both $\mu$-OR and $\partial$-OR (Table 1). Thus, $\eta^{6}$-coordination of $\mathrm{Cp} * \mathrm{Rh}$ to the tyrosine residue of [ $\mathrm{Tyr}^{1}$ ]-leu-enkephalin lowered its potency toward cells expressing only $\mu$-OR or $\partial$-OR, but had a similar potency as $\left[\right.$ Tyr $^{1}$ ]-leu-enkephalin for cells co- expressing both $\mu$-OR and $\partial-\mathrm{OR}$, which coincided with previous findings of distinctly different pharmacological profiles for co-expressed versus receptor cells alone, and complements the results with peptide, [Tyr $\left.{ }^{1}\right]$-leuenkephalin. Moreover, a competitive binding experiment was performed on the GPCR somatostatin receptor, rat $\mathrm{SST}_{2}$, with positive tumoral acinar pancreatic cells (AR42J),

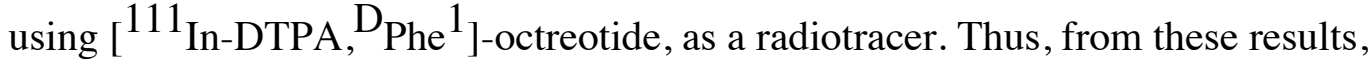


$\left[\left(\eta^{6}-\mathrm{Cp} * \mathrm{Rh}\right)-\mathrm{Tyr}^{3}\right)$-octreotide $](\mathrm{OTf})_{2}$ had a very similar affinity for the $\mathrm{SST}_{2}$ receptor in comparison to $\left[\mathrm{Tyr}^{3}\right]$-octreotide (Table 1$) .^{20}$ Apparently, the Cp*Rh moiety $\eta^{6}$-bonded

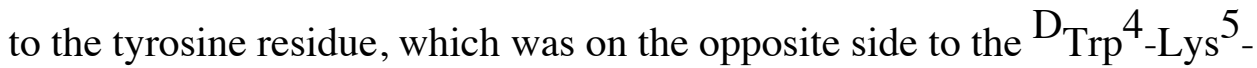
pharmacophore (Figure 2), had little effect on the binding of $\left[\left(\eta^{6}-\mathrm{Cp} * \mathrm{Rh}\right)-\mathrm{Tyr}^{3}\right)$ octreotide $](\mathrm{OTf})_{2}$ to the GPCR SST 2 receptor. This result suggested that the $\left[\left(\eta^{6}-\right.\right.$ $\mathrm{Cp}^{*} \mathrm{Rh}$ )- $\mathrm{Tyr}^{3}{ }^{3}$-octreotide](OTf) 2 residue was still an important component in the molecular recognition process, at the $\mathrm{SST}_{2}$ receptor site, and intimated that the flexibility of the receptor site can accommodate major changes in the pharmacophore conformation, but still retain bioactivity. However, the affinity of $\left[\left(\eta^{6}-\mathrm{Cp} * \mathrm{Rh}\right)-\mathrm{Tyr}{ }^{3}\right)$ octreotide](OTf $)_{2}$ for the $\mathrm{SST}_{2}$ receptor, which has been shown to be the most abundant SST subtype in human tumors expressing the somatostatin receptors, was also found to be in the range of other somatostatin peptides.

In other bioassay experiments, the consequence of this $\mathrm{Cp} * \mathrm{Rh}$ modification of peptides, $\left[\mathrm{Tyr}^{1}\right]$-leu-enkephalin and $\left[\mathrm{Tyr}^{3}\right]$-octreotide, on the in vitro growth inhibition of the breast adenocarcinoma cell line (MCF7) and the human colon carcinoma (HT29) cell line was determined. For these bioassays, both $\left[\left(\eta^{6}-\mathrm{Cp} * \mathrm{Rh}-\mathrm{Tyr}{ }^{1}\right)\right.$-leuenkephalin] $(\mathrm{OTf})_{2}$ and $\left[\left(\eta^{6}-\mathrm{Cp} * \mathrm{Rh}^{-\mathrm{Tyr}^{3}}\right)\right.$-octreotide $\left.] \mathrm{OTf}\right)_{2}$ were tested and compared to peptides, $\left[\right.$ Tyr $\left.^{1}\right]$-leu-enkephalin and $\left[\right.$ Tyr $\left.^{3}\right]$-octreotide (Table 1$)$. Interestingly, both $\left[\left(\eta^{6}\right.\right.$ $\left.\mathrm{Cp}^{*} \mathrm{Rh}-\mathrm{Tyr}^{1}\right)$-leu-enkephalin](OTf $)_{2}$ and $\left[\left(\eta^{6}-\mathrm{Cp}^{*} \mathrm{Rh}^{-} \mathrm{Tyr}^{3}\right)\right.$-octreotide $\left.] \mathrm{OTf}\right)_{2}$ had very similar $\mathrm{IC}_{50}$ values with those of peptides $\left[\mathrm{Tyr}^{1}\right]$-leu-enkephalin and $\left[\mathrm{Tyr}^{3}\right]$-octreotide, for both cell lines (Table 1). Since the MCF7 and HT29 cell lines were found to express opioid and somatostatin receptors, among others, this growth inhibition activity observed for both $\mathrm{Cp} * \mathrm{Rh}$-peptide complexes might be directly related to their GPCR binding regimes..$^{20}$ These latter bioassay studies also confirmed the findings of the GPCR binding experiments, in that, the antiproliferative activity of peptides [Tyr ${ }^{1}$-leu-enkephalin and $\left[\mathrm{Tyr}^{3}\right]$-octreotide was still retained by the $\mathrm{Cp} * \mathrm{Rh}$ modification of their tyrosine residues, complexes, and to reiterate, provided information on the potential role of the opioid and somatostatin receptors in the growth inhibition of MCF7 and HT29 cancer cells. 
Table 2. Comparison of the GPCR Receptor Binding and Cancer Cell Growth Inhibition Activity of [ $\left(\eta^{6}-\mathrm{Cp} * \mathrm{Rh}-\mathrm{Tyr}^{1}\right)$-leu-enkephalin $](\mathrm{OTf})_{2}$ and $\left[\left(\eta^{6}-\mathrm{Cp} * \mathrm{Rh}-\mathrm{Tyr}^{3}\right)\right.$-octreotide $](\mathrm{OTf})_{2}$ with their Peptide Precursors

\section{Receptor}

\section{Substrates}

$$
\left[\left(\eta^{6}-\mathrm{Cp} * \mathrm{Rh}-\mathrm{Tyr}^{3}\right) \text {-octreotide }\right](\mathrm{OTf})_{2} \quad\left[\mathrm{Tyr}^{3}\right] \text {-octreotide }
$$
$\mathrm{SST}_{2}^{\mathrm{a}}\left(\mathrm{IC}_{50}, \mathrm{nM}\right)$
15.8
13.8

$\mathrm{IC}_{50}$ Growth Inhibition $(\mu \mathrm{M})$

MCF7

HT29

d-OR ${ }^{\mathrm{c}}$

15.6

4.4

$\mu-\mathrm{OR}+\boldsymbol{\partial}-\mathrm{OR}$

3.4

3.3

$\mathrm{IC}_{50}$ Growth Inhibition ( $\left.\mu \mathrm{M}\right)$

MCF7

HT29

${ }^{a}$ Somatostatin receptor. ${ }^{b} \mu$-Opioid receptor. ${ }^{c} \partial$-Opioid receptor. 


\section{Overview of the Bioorganometallic Chemistry Discipline}

Since the x-ray crystal structure of the NiFe hydrogenase was determined in 1995 by Fontecilla-Camps et al., Nature, 1995, 373, 580, and found to be an ancient organometallic complex with the NiFe metal centers being bound to $\mathrm{CN}$ and $\mathrm{CO}$ groups; i.e, C-M bonds, as well as our own discovery in 1983, that methyl and phenylarsonic acids were natural products in ancient, algae kerogen formations of oil shale, the relevance of the Bioorganometallic Chemistry discipline has risen dramatically. In 2002, Gérard Jaouen and I organized the First International Symposium on Bioorganometallic Chemistry (ISBOMC) that was held in Paris, and continues to meet every two years at different international locations; this year, 2014, Vienna, Austria, Bernhard Keppler, Chairman. The ISBOMC meetings have provided an international forum for all the relevant topics, and will continue, in the future, to be an important arena for disseminating the progress of new and important areas of the Bioorganometallic Chemistry discipline.

\section{Acknowledgments}

I wish to thank all the undergraduate students and postdoctoral fellows that worked with me at LBNL/UC Berkeley, as well as the senior colleagues, that are named in the publications, for the important contributions they made to the Bioorganometallic Chemistry program we developed together. Special thanks to Gérard Jaouen and Paul Dyson, who helped me initiate an organometallic pharmaceutical program, and Nils Metzler-Nolte, who facilitated my research ideas on $\mathrm{Cp} * \mathrm{Rh}-\mathrm{GPCR}$ peptide complexes during visiting professorships in their respective laboratories in Paris, Lausanne, and Bochum. Support by the U. S. Department of Energy and LBNL Director's Funds are gratefully acknowledged under Contract No. DE AC02-05CH11231, while National Institute of Environmental Health Sciences is also acknowledged for support. I would also like to thank Elsevier, and my good friend and colleague, Rick Adams, Associate Editor, Journal of Organometallic Chemistry, for sponsoring the ISBOMC Award, since its inception.

${ }^{*}$ To whom all correspondence should be sent: rhfish@lbl.gov

\section{References}

1. (a) R. H. Fish, E. C. Kimmel, J. E. Casida, J. Organometal. Chem. 1975, 93, C1.

(b) R. H. Fish, E.C. Kimmel, J. E. Casida, J. Organometal. Chem. 1976, 118, 41.

(c) R. H. Fish, J. E. Casida, E. C. Kimmel, ACS Symposium Series. 1978, 82, 82.

2. (a) R. H. Fish, J. E. Casida, E.C. Kimmel, Tetrahedron Lett. 1978, 3515.

(b) R. H. Fish, B.M. Broline, J. Organometal. Chem. 1977, 136, C41.

(c) R. H. Fish, B.M. Broline, J. Organometal. Chem. 1978, 159. Page?

3. R. H. Fish, R. T. Price, Organometallics 1989 8, 225. 
4. D. de Vos, R. Willem, M. Gielen, K. E.; K. E. van Wingerden, K. Nooter, Metal-Based Drugs, 1998, 5, 179.

5. (a) R.H, Fish, F. E. Brinckman, K. L. Jewett, Environ. Sci. Technol. 1982, 16, 174.

(b) C. S. Weiss, K. L. Jewett, F . E. Brinckman, R. H. Fish, NBS Spec. Publ. (U. S.) 1981, No. 618, 197. (c) R. H Fish, ACS Symp. Ser. 1983, No. 230, 423.

6. R. H. Fish, W. Walker, R. S. Tannous, Energy \& Fuels, 1987, 1, 243

7. R. H. Fish, R.S. Tannous, W. Walker, C.S. Weiss, F.E. Brinckman, J. Chem. Soc., Chem. Commun. 1983, 490.

8. R. H. Fish, R. S. Tannous, Organometallics 1982, 1, 1238.

9. D. P. Smith, H. Chen, S. Ogo, A. I. Elduque, M. Eisenstein, M. M. Olmstead, R. H. Fish, Organometallics, 2014, 33, 2389, and references therein.

10. S. Ogo, O. Buriez, J. B. Kerr, R. H. Fish, J. Organomet. Chem. 1999, 589, 66.

11. (a) H. Chen, S. Ogo, R. H. Fish, J. Am. Chem. Soc. 1996, 118, 4993. (b) S. Ogo, S.Nakamura, H. Chen, K. Isobe, Y. Watanabe, R. H. Fish, J. Org. Chem. 1998, 63, 7151.

(c) R. Bakhtiar, H. Chen, S. Ogo, R. H. Fish, Chem. Commun. 1997, 2135.

(d) A. Elduque, D. Carmona, L. A. Oro, M. Eisenstein, R. H.Fish, J. Organometal.

Chem., 2003, 668, 123.

12. H. C. Lo, C. Leiva, O. Buriez, J. B. Kerr, M. M. Olmstead, R. H. Fish, Inorg. Chem. 2001 40, 6705.

13. H. C. Lo, R. H. Fish, Angew. Chem. Int. Ed. 2002, 41, 478.

14. J. D. Ryan, R. H. Fish, D. S. Clark, ChemBioChem 2008, 9, 2579

15. J. Lutz, F. Hollmann, T. V. Ho, A. Schnyder, R. H. Fish, A. Schmid, J. Organometal. Chem. 2004, 689, 4783.

16. (a) R. H. Fish, G. Jaouen, Organometallics 2003, 22, 2166, and references therein;

(b) C. S. Allardyce, P. J. Dyson, D. J. Ellis, S. L. Heath, Chem. Commun. 2001, 1396;

(c) C. S. Allardyce, P. J. Dyson, D. J. Ellis, P. A. Salter, R. Scopelliti, J. Organometal. Chem. 2003, 668, 35 (d) R. E. Morris, R. E. Aird, P. D. Murdoch, H. M. Chen, J. Cummings, N. D. Hughes, S. Parsons, A. Parkin, G. Boyd, G. D. I. Jodrell, P. J. Sadler, J. Med. Chem., 2001, 44, 3621; (e) H. Chen, J. A. Parkinson, S. Parsons, R. A. Coxall, R. O. Gould, P. J. Sadler, J. Am. Chem. Soc. 2002, 124, 3064; (f) F. Wang, H. Chen, J. A. Parkinson, P. D. Murdoch, P. J. Sadler, Inorg. Chem. 2002, 41, 4509; (g) G. Jaouen, S. Top, A. Vessières, R. Alberto, J. Organomet. Chem. 2000, 600, 25 and references therein. (h) G. Jaouen, Chemistry in Britain 2001, 36; 
(i) P. Köpf-Maier, Eur. J. Chim. Pharmacol. 1994, 47, 1. (j) M. Melchart, P. J. Sadler, in Bioorganometallics: G. Jaouen, Ed., Wiley-VCH, 2005, Chap 2, p39. (k) G. Jaouen, S. Top, A. Vessières, in Bioorganometallics: G. Jaouen, Ed., Wiley-VCH, 2005, Chap 3, p65. (1) R. Alberto, in Bioorganometallics: G. Jaouen, Ed., Wiley-VCH, 2005, Chap 4, p97. (m) R. Dagani, Chemical and Engineering News 2002, 80, 23. September 16, 2002 issue. "The Bio Side of Organometallics." (n) A. Dorcier, C. G. Hartinger, R. Scopelliti, R. H. Fish, B. K. Keppler, P. J. Dyson, J. Inorg. Biochem. 2008, 102, 1066.(o) A. F. A. Peacock, P. J. Sadler, Chem. Asian J. 2008, 11, 1886.(p) C. G. Hartinger, P. J. Dyson, Chem. Soc. Rev., 2009, 38, 391. (q) K. Strohfeldt, M. Tacke, Chem. Soc. Rev., 2008, 37, 1174.

17. Top, S. ; Efremenko, I., Rager, N.-M; Vessieres, A.; Jaouen, G., Fish. R. H. Inorg. Chem. 2011, 50, 271.

18. I. Efremenko, S. Top, J. M. L. Martin, R. H. Fish, Dalton Trans. 2009, 4334.

19. N. Metzler-Nolte, Labelling of Peptides and PNA with Organometallics. In Bioorganometallics; Jaouen, G., Ed.; Wiley-VCH: Weinheim, 2005, pp125-179.

20. H. B. Albada, F. Wieberneit, I. Dijkgraaf, J. H. Harvey, J. L. Whistler, R. Stoll, N. Metzler-Nolte, R. H. Fish J. Am. Chem. Soc. 2012, 134, 10321, and references therein. 


\section{Graphical Abstract}

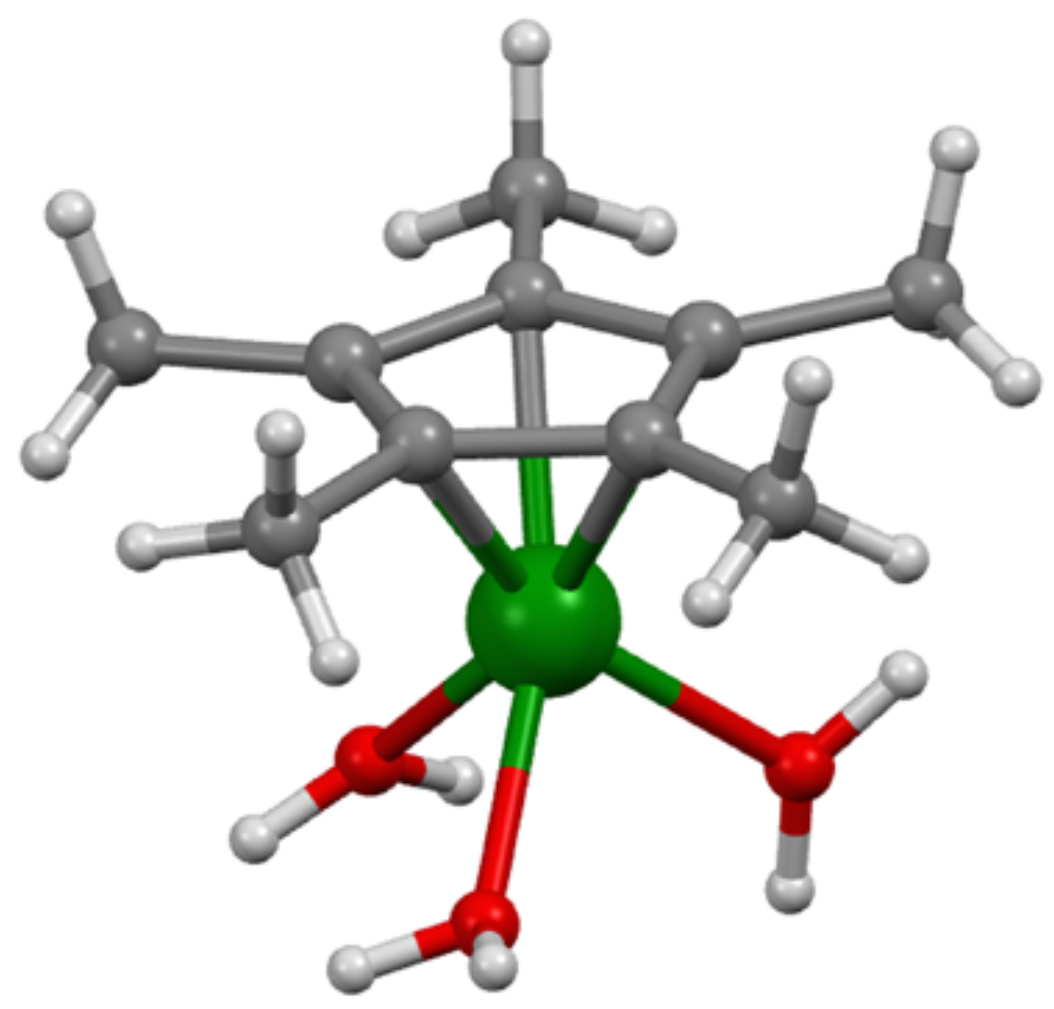

The synthon, dication $\left[\mathrm{Cp}^{*} \mathrm{Rh}\left(\mathrm{H}_{2} \mathrm{O}\right)_{3}\right](\mathrm{OTf})_{2}$, with its X-ray structure shown, was a key to the preparation of many of our $\mathrm{Cp}^{*} \mathrm{Rh}$ complexes reported in this ISBOMC'14 award paper. It's mononuclear structure is $\mathrm{pH}$ dependent, and stable from $\mathrm{pH} 2-5$, while at higher $\mathrm{pH}$ values, 5-7, a dynamic equilibrium is initiated to a putative intermediate, $\left[\mathrm{Cp} * \mathrm{Rh}(\mu-\mathrm{OH})\left(\mathrm{H}_{2} \mathrm{O}\right)\right]_{2}(\mathrm{OTf})_{2}$, which at $\mathrm{pH}>7$ forms the thermodynamic sink, $\left[(\mathrm{Cp} * \mathrm{Rh})_{2}(\mu-\mathrm{OH})_{3}\right](\mathrm{OH})$. Thus, the $\mathrm{Cp} * \mathrm{Rh}$ complexes found in the award paper emanate from all three $\mathrm{Cp} * \mathrm{Rh}$ aqua complexes, as a function of $\mathrm{pH}$. 